This item was submitted to Loughborough's Research Repository by the author.

Items in Figshare are protected by copyright, with all rights reserved, unless otherwise indicated.

\title{
Unpacking the relationship between a coopetition-oriented mindset and coopetition-oriented behaviours
}

PLEASE CITE THE PUBLISHED VERSION

https://doi.org/10.1108/JBIM-03-2020-0165

PUBLISHER

Emerald

VERSION

AM (Accepted Manuscript)

\section{PUBLISHER STATEMENT}

This paper was accepted for publication in the journal Journal of Business and Industrial Marketing and the definitive published version is available at https://doi.org/10.1108/JBIM-03-2020-0165

LICENCE

CC BY-NC-ND 4.0

\section{REPOSITORY RECORD}

Crick, Jim. 2020. "Unpacking the Relationship Between a Coopetition-oriented Mindset and Coopetitionoriented Behaviours”. Loughborough University. https://hdl.handle.net/2134/12605465.v1. 


\title{
UNPACKING THE RELATIONSHIP BETWEEN A COOPETITION-ORIENTED MIND-SET AND COOPETITION-ORIENTED BEHAVIOURS
}

\begin{abstract}
Purpose - Earlier work has suggested that assumptions, values, and beliefs about the importance of cooperating with competitors (a coopetition-oriented mind-set) should manifest into behavioural forms of coopetition, such as resource and capability-sharing activities. Yet, limited research surrounds the complexities of this link. Thus, guided by resource-based theory and the relational view, this current paper unpacks the relationship between a coopetition-oriented mind-set and coopetition-oriented behaviours under the moderating roles of industry experience and degree of internationalisation.
\end{abstract}

Design/methodology/approach - The chosen empirical context was the Canadian wine industry, since wine producers are often involved in coopetition strategies and have varying degrees of internationalisation. Preliminary interview data were collected from 18 managers to shape the operationalisations. Then, survey data were collected from 195 Canadian wine producers. After checking the statistical data for all major assessments of reliability and validity (together with common method variance), the hypothesised and control paths were tested through hierarchical regression.

Findings - A coopetition-oriented mind-set had a positive and significant association with coopetitionoriented behaviours. Surprisingly, this link was negatively moderated by industry experience. Additionally, degree of internationalisation yielded a positive moderation effect. These moderators highlight situations where a coopetition-oriented mind-set is (and is not) likely to manifest into coopetition activities.

Practical implications - If firms aim to engage in behavioural forms of coopetition, they should manage assumptions, values, and beliefs associated with the advantages of collaborating with their competitors. Industry experience can limit the extent to which business' coopetition-oriented mind-sets manifest into coopetition-oriented behaviours. This could be explained by decision-makers possessing information that discourages them from working with certain (untrustworthy) rivals because of the potential harmful effects on their performance. Companies should utilise their industry experience to avoid working with rival entities that will create negative outcomes, like tensions (e.g., conflict, power imbalances, and opportunistic behaviours), lost intellectual property, and diluted competitive advantages. Nonetheless, industry experience might signify that there are more risks than rewards linked with these business-tobusiness marketing strategies. Higher-levels of internationalisation can help firms to recognise that coopetition-oriented behaviours may lead to performance-enhancing opportunities in their overseas markets.

Originality/value - This investigation contributes to the business-to-business marketing literature with new evidence on how organisations can foster a coopetition-oriented mind-set to engage in coopetition strategies. The negative moderation effect from industry experience highlights that knowledge of competitors' activities can limit the extent to which coopetition-oriented behaviours are implemented. Moreover, the positive interaction effect from degree of internationalisation extends the growing body of knowledge pertaining to coopetition in an international arena. Collectively, these results show that while a coopetition-oriented mind-set is a critical driver of coopetition-oriented behaviours, there are certain contingencies that can strengthen or weaken this association. Lastly, by integrating resource-based theory and the relational view, this article could explore the different forms of coopetition, in terms of organisation-wide mind-sets and firm-level behaviours. This paper concludes with some managerial recommendations, alongside a series of limitations and avenues for future research.

Keywords - Coopetition-oriented mind-sets, coopetition-oriented behaviours, industry experience, degree of internationalisation, resource-based theory, relational view.

Classification - Research paper. 


\section{Introduction}

Over the last twenty years, there has been a growing interest surrounding coopetition-oriented behaviours (also known as coopetition activities or coopetition strategies) throughout the broader business-tobusiness marketing literature (Bengtsson and Kock, 2000; Rusko, 2011; Park et al., 2014; Bengtsson and Raza-Ullah, 2016; Felzensztein et al., 2018; McGrath et al., 2019; Lascaux, 2020). These activities are described as being the interplay between cooperation and competition, whereby, rival organisations (especially smaller-sized entities) share resources (e.g., equipment and hardware) and capabilities (e.g., knowledge and experience) for mutually-beneficial outcomes (Bengtsson and Kock, 1999; Bouncken and Kraus, 2013; Bengtsson et al., 2016; Geldes et al., 2017; Hannah and Eisenhardt, 2018; Leite et al., 2018; Yan et al., 2020). Behavioural forms of coopetition are defined as "a paradoxical relationship between two or more actors, regardless of whether they are in horizontal or vertical relationships, simultaneously involved in cooperative and competitive interactions" (Bengtsson and Kock, 2014, p. 180). Since coopetition is intended for firms to access new resources, capabilities, and opportunities that would not exist under individualistic business models, it is not surprising that scholars have conducted a considerable amount of research towards understanding the relationship between these strategies (or similar activities, like inter-firm cooperation) and company performance (see Rich, 2003; Rindfleisch and Moorman, 2003; Ritala, 2012; Geldes et al., 2015; Shu et al., 2017; Basterretxea et al., 2019; Estrada and Dong, 2020).

That said, by focusing on the link between coopetition and company performance, many academics have overlooked the antecedents of these business-to-business marketing strategies (as noted by Bouncken et al., 2015; Hoffmann et al., 2018; Czakon et al., 2020). This means that it is unclear how organisations can foster the interplay between cooperation and competition. Within this under-researched area, some work has been conducted on coopetition-oriented mind-sets (assumptions, values, and beliefs associated with the importance of cooperating with competing firms) and their link with behavioural forms of coopetition, like resource and capability-sharing activities (see Brandenburger and Nalebuff, 1996; 
Gnyawali and Charleton, 2018; Crick and Crick, 2019). Nonetheless, this association has been evaluated as being straightforward, whereby, it is unaffected by certain contingencies. Indeed, there have been several recent calls for research to explore the complexities of the coopetition construct (see Mattsson and Tidstrom, 2015; Gnyawali et al., 2016; Shu et al., 2017; Cui et al., 2018; Crick, 2019). Thus, it could be that this relationship becomes stronger if firms possess experience within their markets, including knowledge of their competitors' strengths and weaknesses (linking with Gnyawali and Park, 2011; Granata et al., 2018; Estrada and Dong, 2020). In other words, industry experience could help companies to manage their coopetition-oriented mind-sets, so that they work with trustworthy rivals for mutuallybeneficial outcomes.

Another research gap surrounds whether internationalised firms engage in coopetition (or comparable business-to-business marketing activities) differently to those targeting domestic markets (see Kock et al., 2010; Felzensztein et al., 2014; Faroque et al., 2017; Shu et al., 2017; Ryan et al., 2019). That is, most coopetition-based research has focused on businesses collaborating with their competitors to be more successful in domestic (rather than international) arenas (see Bengtsson and Kock, 1999; Ritala and Hurmelinna-Laukkanen, 2013; Czakon and Czernek, 2016; Hannah and Eisenhardt, 2018; Crick, 2020). As such, it could be that the coopetition-oriented mind-set - coopetition-oriented behaviours link is affected by organisations' degree of internationalisation. Collectively, these research gaps signify that work should be undertaken to unpack this association to identify how firms can best-manage the interplay between cooperation and competition (extending Brandenburger and Nalebuff, 1996; Tidstrom, 2009; Mattsson and Tidstrom, 2015; Leite et al., 2018; McGrath et al., 2019). More formally, under resourcebased theory and the relational view (Barney, 1991; Dyer and Singh, 1998; Lavie, 2006; Dyer et al., 2018), the objective of this current study is to evaluate the relationship between a coopetition-oriented mind-set and coopetition-oriented behaviours under the moderating roles of industry experience and degree of internationalisation. By achieving this research objective, the following three contributions are made to strengthen the existing body of knowledge: 
1. Improved conceptualisations are made into the multiple forms of coopetition, in terms of whether they exist as an organisation-wide mind-set and/or a set of firm-level behaviours (extending Brandenburger and Nalebuff, 1996; Bengtsson and Kock, 2014; Bouncken et al., 2015; Gnyawali and Charleton, 2018; McGrath et al., 2019).

2. Through the moderating roles of industry experience and degree of internationalisation, novel insights are offered surrounding the contingencies that can help or hinder organisations from best-managing the interplay between cooperation and competition (building upon Gnyawali and Park, 2011; Bengtsson et al., 2016; Hoffmann et al., 2018; Estrada and Dong, 2020).

3. New evidence is presented on how smaller-sized companies can engage in international-level coopetition strategies (following Kock et al., 2010; Felzensztein et al., 2014; Shu et al., 2017; Ryan et al., 2019; Crick and Crick, 2020), as opposed to focusing on larger corporations, such as those involved in strategic alliances (as per Luo, 2005; Luo and Tung, 2007; Robson et al., 2012; Liu et al., 2019).

To make these three contributions, this paper is divided as follows. First, the conceptual framework is presented. Second, the adopted methodology is described. Third, the empirical results are outlined. Fourth, these results are discussed in relation to the extant literature. Fifth, the article is concluded, alongside some managerial recommendations and a series of limitations and avenues for future research.

\section{Theory and hypotheses}

Resource-based theory and the relational view

The resource-based view examines the link between organisations' resources and capabilities and their performance (Barney et al., 2011; Wernerfelt, 2014). A key assumption of this theory is that larger businesses, with more resources and capabilities, can out-perform smaller rivals, with fewer assets at their disposal (Hunt and Morgan, 1995; Morgan, 2012; Barney, 2014; Cortez and Johnston, 2019). According to Barney (1991), the resource-based view is underpinned by the value, rarity, inimitability, and 
non-substitutability (VRIN) framework, which assesses the performance outcomes of organisational resources and capabilities. The VRIN framework has driven the expansion of resource-based theory to show how companies can utilise their assets to secure sustainable competitive advantages (as noted by Kozlenkova et al., 2014). A sustainable competitive advantage refers to superior business performance over rival entities that withstands the test of time and the volatility of the external market (Vorhies and Morgan, 2005; Kumar and Pansari, 2016; Bel, 2018). While this current paper does not draw exclusively upon the VRIN framework, it has shaped how resource-based theory can be employed to conceptualise the performance outcomes of firms' resources and capabilities. On that note, sustainable competitive advantages are not the only measure of success under resource-based theory, as academics have considered other assessments, such as customer satisfaction, sales, and profitability (see Ray et al., 2004; Morgan et al., 2009; Katsikeas et al., 2016). That is, some managers (especially in smaller-sized companies) do not seek to obtain sustainable competitive advantages and measure performance in different ways (reference withheld; Crick et al., 2018).

Indeed, the resource-based view has been extended in other respects. These developments must be accounted for when applying the holistic nature of this theoretical lens to the different forms of coopetition. Most notably, Barney (2001) and Priem and Butler (2001) engaged in a debate concerning the future directions and applications of this perspective. Although they disagreed over some issues, these authors reached a consensus that resource-based theory should be adapted. For example, they discussed that scholars should differentiate resources and capabilities, since tangible and intangible assets have different purposes within competitive strategies (following Morgan et al., 2009; O'Cass et al., 2015). In addition, Barney (2001) and Priem and Butler (2001) evaluated how aspects of the competitive business environment (e.g., competitive intensity) could serve as a contingency that can affect the performance outcomes of organisational resources and capabilities (evaluated by Cadogan et al., 2009; Crick and Crick, 2020). In this current paper, these developments to the resource-based view are considered when using this lens in the subsequent conceptualisations. Resource-based theory has been related to the 
coopetition literature to suggest that some entities cooperate with their competitors to be more successful than if they operated using their own resources and capabilities (O'Dwyer et al., 2011; Hannah and Eisenhardt, 2018; Crick, 2019). As an illustration, Felzensztein et al. (2014) found that if companies collaborate with their rivals, they can learn new ways to deliver value to their customers (domestically and internationally) and lower their operating costs - resulting in higher-levels of financial performance.

In fact, traditionally, resource-based theory focused on internal resources and capabilities (see Wernerfelt, 1984; Peteraf, 1993; Conner and Prahalad, 1996). Over time, academics have investigated how firms might acquire tangible and intangible assets from outside of their organisations, such as working with external partners (e.g., competitors) for mutual-advantages (see Acquaah, 2007; Sraha et al., 2020). This includes how decision-makers can be market-led, in which they assess the competitive dynamics within their sectors to formulate performance-enhancing strategies (Mu et al., 2018). Yet, instead of attempting to derail competitors (as per Day, 2014), coopetition provides a collaborative perspective to the external focus of the resource-based view (following Gnyawali and Charleton, 2018; reference withheld). Hence, these extensions help to justify why this theoretical perspective was suitable for studying the different forms of coopetition. That said, the resource-based view does not fully-account for the collaborative aspects of coopetition-oriented behaviours (Hunt and Derozier, 2004; Crick and Crick, 2020). The relational view covers how high-quality inter-firm relationships can be used to yield mutually-beneficial performance outcomes (Dyer and Singh, 1998; Coviello and Brodie, 2001). By integrating resource-based theory with the relational view, this current study explored the cooperative and competitive aspects of coopetition activities and their link with a coopetition-oriented mind-set (Lavie, 2006; Dyer et al., 2018; Crick, 2020). In doing so, this investigation builds upon Barney's (2018) article that discussed how the resource-based view should be used to explain that certain firms collaborate with key stakeholders (e.g., rivals) to survive and grow within their markets.

For clarity, Barney (2018) focused on wider stakeholders, noting that although organisational resources and capabilities might influence performance, firms must also have strong connections with internal and 
external partners. A vital feature of Barney's (2018) paper was that management teams (including within smaller-sized firms) should possess the social capital to complement their tangible and intangible assets (building upon Acquaah, 2007; Kor and Mesko, 2013). In this current investigation, one stakeholder group is examined (namely, competitors) and is infused with resource-based theory and the relational view to unpack the relationship between a coopetition-oriented mind-set and coopetition-oriented behaviours. It is appreciated that using an integration of resource-based theory and the relational view is just one conceptual tool of making this contribution to knowledge. For example, business-to-business marketing scholars have developed the interaction and network approach within the Industrial Marketing and Purchasing (IMP) Group (see Tikkanen, 1998; Finch et al., 2012). This framework shows how actors develop networks (in positive and negative capacities) over time (see Wheeler et al., 1996). The interaction and network approach is presented as a model, rather than a broader management or marketing theory that can be evaluated (depicted by Brennan et al., 2017), as per resource-based theory and the relational view.

Instead of concentrating on individual companies, or their goods and services, the interaction and network approach has shown the value of inter-firm networks, such as through trust, temporal issues (e.g., the length of partnerships), and the closeness of the businesses involved (Holmlund, 2004). Furthermore, it accounts for external factors, such as the volatility within the competitive business environment and its effect on business-to-business marketing relationships (Kot and Leszczynski, 2020). This means that the interaction and network approach does not exist in one form, but rather, is a collection of assumptions and applications. This includes being applied to various inter-firm partnerships, not just coopetition activities (Moller, 2013). The relational aspects of the interaction and network approach might cover some critical issues within the business-to-business marketing literature. However, an integration of resourcebased theory and the relational view was deemed to be a more appropriate (established) lens to evaluate 
the multiple-levels of the coopetition construct ${ }^{1}$ (following Lavie, 2006; Dyer et al., 2018; Crick, 2019). Key reasons pertained to them encapsulating that coopetition is comprised of collaborative and rivalrous dimensions (shown by Gnyawali and Charleton, 2018; Crick and Crick, 2020). The interaction and network approach was seemingly generic, in which it is positioned at an aggregate-level and not directly related to coopetition (Brennan et al., 2017).

\section{Conceptual framework}

Guided by resource-based theory and the relational view (Barney, 1991; Dyer and Singh, 1998; Lavie, 2006; Dyer et al., 2018), this paper's conceptual framework (Figure 1) contained three research hypotheses and two control paths. First, it was expected that a coopetition-oriented mind-set positively impacts coopetition-oriented behaviours (see Brandenburger and Nalebuff, 1996; Gnyawali and Charleton, 2018; Crick and Crick, 2019). Second, following on, this link was anticipated to be positively moderated by industry experience and degree of internationalisation (building upon Kock et al., 2010; Kor and Mesko, 2013; Felzensztein et al., 2014; Shu et al., 2017; Estrada and Dong, 2020). Third, the outcome variable (namely, coopetition-oriented behaviours) was controlled by firm size and firm age, as additional factors that might explain its variance (following Rusko, 2011; Bengtsson et al., 2016; Barney, 2018; Czakon et al., 2020).

\section{[Insert Figure 1 about here]}

\section{Coopetition-oriented mind-sets and coopetition-oriented behaviours}

Linking with resource-based theory and the relational view (see Lavie, 2006; Dyer et al., 2018; Crick, 2019), a coopetition-oriented mind-set is the extent to which organisations possess assumptions, values, and beliefs about cooperating with competitors (Brandenburger and Nalebuff, 1996; Gnyawali and Park,

\footnotetext{
1 The author would like to thank an anonymous reviewer for requesting that the interaction and network approach should be conceptualised. Nonetheless, resource-based theory and the relational view were deemed to be more suitable theoretical lenses within this current study.
} 
2011; Bouncken et al., 2015). Mind-sets are a vital aspect of corporate cultures, as they surround the issue(s) that managers and functional-level employees perceive to be critical drivers of their performance (Prahalad and Bettis, 1986; Kor and Mesko, 2013). For example, Homburg and Pflesser (2000) examined market-oriented corporate cultures. They argued that when every member of a firm (across all departments and hierarchies) believes that creating value for customers is an important activity, their market-oriented mind-set will infuse into market-oriented behaviours, namely, the generation of, dissemination of, and responsiveness to market intelligence (Jaworski and Kohli, 1993; Cadogan et al., 2009; Carbonell and Escudero, 2010; Ozturan et al., 2014; Hamzah et al., 2020). Returning to the interplay between cooperation and competition, with lower-degrees of a coopetition-oriented mind-set, firms are likely to believe that collaborating with their competitors is not a performance-driving activity (Bouncken et al., 2015; Gnyawali and Charleton, 2018; McGrath et al., 2019).

This might be influenced by firms being aware of the risks of engaging in coopetition, such as tensions (e.g., conflict, power imbalances, and opportunistic behaviours), lost intellectual property, and diluted competitive advantages (Luo et al., 2007; Tidstrom, 2009; Raza-Ullah et al., 2014; Bouncken et al., 2018; Tidstrom et al., 2018; Crick et al., 2021). Also, some organisations choose not to engage in coopetition because they are equipped with certain assets that allow them to create value for their customers without a need to work with industry rivals (Felzensztein et al., 2012; Bengtsson and Raza-Ullah, 2016; Geldes et al., 2017; Granata et al., 2018). In these instances, a low coopetition-oriented mind-set would be reflected in a view that company performance is driven by other strategies than coopetition (Gnyawali and Park, 2011; Bouncken and Kraus, 2013; Leite et al., 2018). With higher-degrees of a coopetitionoriented mind-set, organisations are likely to become aware of the potential benefits of working with industry rivals, including improved performance (e.g., sales), new assets, reduced operating costs, and increased customer satisfaction (Rich, 2003; Rindfleisch and Moorman, 2003; Hannah and Eisenhardt, 2018; Yan et al., 2020). Put another way, if companies are conscious of how coopetition can help them to be more successful in their markets, managers and functional-level employees might be more inclined 
to engage in behavioural forms of coopetition (Gnyawali and Park, 2011; Bouncken et al., 2015; Crick, 2018; McGrath et al., 2019). Therefore, it follows that:

H1. A coopetition-oriented mind-set has a positive relationship with coopetition-oriented behaviours.

\section{Moderating role of industry experience}

Under resource-based theory and the relational view (Dyer and Singh, 1998; Lavie, 2006), while a coopetition-oriented mind-set should positively impact coopetition-oriented behaviours (Brandenburger and Nalebuff, 1996; Gnyawali and Park, 2011; Gnyawali and Charleton, 2018; Crick and Crick, 2019; McGrath et al., 2019), there could be certain contingencies affecting this association. Specifically, if companies possess valuable knowledge about their sectors, they might be aware of their competitors' activities, as well as their strengths and weaknesses (Narver and Slater, 1990; Slater and Narver, 2000; Johnson et al., 2012; Russo et al., 2017). Consequently, businesses might be able to harness their industry experience to decide to work with similar (complementary) rivals that they can trust to obtain mutually-beneficial outcomes (following Felzensztein and Deans, 2013; Geldes et al., 2015; Granata et al., 2018; Lascaux, 2020). As noted earlier, coopetition can be a risky business-to-business marketing strategy, since it does not always lead to higher-levels of company performance (see Luo et al., 2007; Ritala and Hurmelinna-Laukkanen, 2013; Park et al., 2014; Tidstrom et al., 2018; Crick, 2019). In fact, if firms collaborate with untrustworthy competitors, they can experience a range of negative outcomes that can hurt their brand, lose sales, increase costs, and decrease productivity (Tidstrom, 2014; Mattsson and Tidstrom, 2015; Czakon and Czernek, 2016; Bouncken et al., 2018).

With lower-levels of industry experience, organisations might be hesitant to engage in coopetition activities due to these perceived risks (Gnyawali and Park, 2011; Estrada and Dong, 2020). For example, companies might be concerned with the prospect of sharing vital resources and capabilities with competitors that will exploit them for their own gains (Tidstrom, 2014; Crick, 2020). In fact, Luo et al. 
(2007) found that if decision-makers work with untrustworthy competitors, there will be a diminishingreturns effect on their financial performance. If this occurs, limited industry experience could prevent firms from harnessing their coopetition-oriented mind-sets to engage in behavioural forms of coopetition (since they are unsure of which rivals that they can trust). However, as industry experience increases, decisionmakers are likely to become more confident about which competitors they can trust, as well as the ones that are targeting similar product-markets to help them to survive and grow within their competitive business environments (Kock et al., 2010; Felzensztein and Deans, 2013; Yan et al., 2020). In other words, businesses might become well-informed (through their social networks) about which competitors can help them to create value for customers, enter new markets (e.g., through exporting), lower overheads, boost productivity, and various other benefits (Kor and Mesko, 2013; Bengtsson et al., 2016; Geldes et al., 2017; Ryan et al., 2019). Nonetheless, this involves the "correct" industry experience, so that firms can pinpoint trustworthy and complementary rivals within their markets (Crick et al., 2021). Otherwise, managers and functional-level employees might make the wrong decision to work with competitors that behave opportunistically (Luo et al., 2007; Tidstrom, 2009).

For clarity, industry experience is conceptualised as an organisational capability that can help companies to select complementary coopetition partners, namely, rival entities that they trust, so that they mitigate some of the dark-sides of these business-to-business marketing strategies (Czakon and Czernek, 2016; Lascaux, 2020). Such market-level knowledge should develop with time, as management teams learn about the dynamics of their sectors and ways to create value for their customers (Narver and Slater, 1990; Slater and Narver, 2000). Moreover, there may be little value in collaborating with competitors that are targeting different product-markets because pooling resources and capabilities may only benefit a limited proportion of the firms involved (Felzensztein et al., 2018; Crick and Crick, 2020). Thus, industry experience could assist decision-makers to cooperate with rivals that can help them to secure mutuallybeneficial outcomes, most notably, higher-levels of performance (Estrada and Dong, 2020). This is especially important for smaller-sized entities that may not have the freedom to waste their resources and 
capabilities in coopetition strategies that have no visible advantages (Bouncken and Kraus, 2013; Crick and Crick, 2016; McGrath et al., 2019). Consequently, industry experience (as a mechanism that can help firms to identify trustworthy and complementary partners) could serve as an underlying factor that assists organisations to foster their coopetition-oriented mind-sets, so that they implement coopetitionoriented behaviours. Hence, it is anticipated that:

H2. The relationship between a coopetition-oriented mind-set and coopetition-oriented behaviours is positively moderated by industry experience.

\section{Moderating role of degree of internationalisation}

Driven by resource-based theory and the relational view (Barney, 1991; Hunt and Derozier, 2004; Crick, 2019), while coopetition has received a lot of interest from business-to-business marketing scholars, most of this work has concentrated on such activities in domestic arenas (see Bengtsson and Kock, 1999; Rich, 2003; Luo et al., 2007; Tidstrom, 2009; Ritala, 2012; Raza-Ullah et al., 2014; Czakon and Czernek, 2016; Hannah and Eisenhardt, 2018; Basterretxea et al., 2019; Estrada and Dong, 2020). In comparison, very little research surrounds how firms engage in international forms of coopetition (e.g., Kock et al., 2010; Felzensztein et al., 2014; Shu et al., 2017; Ryan et al., 2019). In fact, the literature pertaining to coopetition in international markets has focused on larger corporations, such as those involved in strategic alliances (Luo, 2005; Luo and Tung, 2007; Robson et al., 2012; Liu et al., 2019). Hence, there is an opportunity to examine the coopetition-oriented mind-set - coopetition-oriented behaviours relationship under different degrees of internationalisation (organisations' involvement in international markets). In other words, it is of interest to evaluate whether firms can combine the benefits of an internationalised business model (e.g., more customers, superior brand equity, and efficient supply chains) (see Smith et al., 2003; Crick, 2007; Cadogan et al., 2009; reference withheld; Nordin and Lindbergh, 2019) with those from a coopetition-oriented mind-set (building upon Felzensztein et al., 2014; Ryan et al., 2019; Crick and Crick, 2020). 
With lower-degrees of internationalisation, firms might have a steady stream of sales revenues from existing (domestic) customers, which influences their decision to not target overseas markets (Leonidou, 1995; Leckie et al., 2017; Crick et al., 2020; Safari and Saleh, 2020). Thus, entities that have a small international presence might choose not to collaborate with their competitors, as such strategies might distract them from their core operations (Crick, 2018; Granata et al., 2018). Further, these organisations might be conscious of the risks of engaging in coopetition, like tensions (e.g., conflict, power imbalances, and opportunistic behaviours), lost intellectual property, and diluted competitive advantages (Luo et al., 2007; Ritala and Hurmelinna-Laukkanen, 2013; Tidstrom, 2014; Mattsson and Tidstrom, 2015; Czakon and Czernek, 2016; Bouncken et al., 2018; Tidstrom et al., 2018). Consequently, they might decide that their time is better-spent not working with rivals, but rather, positioning their resources and capabilities towards their domestic markets. That said, it is recognised that some businesses cooperate with other organisations (non-competitors) to enter export markets, including agents and distributors, as well as investors (see Lai et al., 2015; reference withheld; Dobrucali, 2020; Sraha et al., 2020). This means that firms might be internationalised and cooperative, but choose not to work with industry rivals within their product-markets. Nonetheless, this current study focuses on the interaction between a coopetitionoriented mind-set and an internationalised business model on behavioural forms of coopetition.

Put another way, it is proposed that internationalised firms might have a greater chance of fostering a coopetition-oriented mind-set than domestically-focused organisations, since they may be seeking the support of industry rivals to enhance their success outside of their home country (Felzensztein et al., 2014; Shu et al., 2017). Hence, with higher-degrees of internationalisation, businesses are anticipated to acknowledge that collaborating with their competitors might help them to be more successful in an international arena (Kock et al., 2010; Ryan et al., 2019). This includes pooling assets to run joint marketing events (e.g., trade shows), lowering market entry costs, and accessing more customers (Bengtsson and Kock, 2000; Frisollo, 2007; Rusko, 2011; Felzenstein et al., 2012; Crick, 2019). That is, internationalisation could be a facet of a business model that drives firms to manage their coopetition- 
oriented mind-sets to engage in behavioural forms of coopetition that benefit them in their overseas markets. To stress this matter, for under-resourced entities, internationalisation could be a performancedriving strategy (reference withheld; Cadogan et al., 2005; Felzensztein et al., 2014; Faroque et al., 2017). From a corporate cultural perspective, there could be certain triggers that help or hinder organisationwide mind-sets from manifesting into firm-level behaviours (Prahalad and Bettis,1986; Homburg and Pflesser, 2000; Kor and Mesko, 2013). Degree of internationalisation could serve as such a trigger that encourages managers and functional-level employees to implement coopetition strategies (building upon Luo, 2005; Luo and Tung, 2007; Shu et al., 2017; Crick and Crick, 2020). Consequently, it is expected that:

H3. The relationship between a coopetition-oriented mind-set and coopetition-oriented behaviours is positively moderated by degree of internationalisation.

\section{Control paths}

In addition to the hypothesised paths, the outcome variable (namely, coopetition-oriented behaviours) was controlled by firm size and firm age. Specifically, under resource-based theory and the relational view, larger businesses have increased scope to engage in coopetition activities due to possessing a greater volume of resources and capabilities to share with industry rivals (Lavie, 2006; Gnyawali and Park, 2011; Rusko, 2011; Gnyawali and Charleton, 2018). Thus, firm size featured as a control path. Also, resource-based theory and the relational view have been adapted to consider various tools that companies use in their strategies than just size-based factors (Coviello and Brodie, 2001; Hunt and Derozier, 2004; Lavie, 2006; Barney, 2018). For example, older entities can harness their heritage to outperform younger rivals, with less experience in their markets (Vorhies et al., 2011). Regarding coopetition, older firms might have stronger insights into which competitors that they should collaborate with (Bouncken and Kraus, 2013; Bengtsson et al., 2016; Crick, 2018; Estrada and Dong, 2020; Lascaux, 
2020). As such, firm age controlled the outcome variable. The adopted methodology follows in the next section.

\section{Methodology}

\section{Empirical context}

An ideal context for coopetition-based research is a sector that hosts high-degrees of cooperativeness and competitiveness (following Bengtsson and Kock, 2000; Rusko, 2011; Geldes et al., 2015; Leite et al., 2018). In this current investigation, the Canadian wine industry was utilised to test the research hypotheses and control paths. The reason being is that wine producers (including those located in Canada) are active in implementing coopetition strategies, in terms of small-scale resource and capabilitysharing activities, as well as more formal strategic alliances (Telfer, 2001; Felzensztein and Deans, 2013; Granata et al., 2018; Crick, 2020). Additionally, wine producers engage in varying degrees of outwards and inwards internationalisation. This includes exporting, sourcing equipment from abroad, and selling their offerings to foreign customers through wine tourism services (Felzensztein et al., 2014; reference withheld; Crick and Crick, 2015). As such, the Canadian wine sector was an appropriate population of interest.

\section{Key informants}

Managers were chosen as the key informants, since these individuals normally possess the authority to determine how their organisation cooperates with industry rivals (Felzensztein et al., 2012; Geldes et al., 2017; McGrath et al., 2019). More importantly, they were anticipated to be qualified to answer questions relating to the constructs within the conceptual framework. This included questions that had an organisation-wide focus, such as the operationalisation of a coopetition-oriented mind-set (as described later). Managers were deemed to be able to comment on the practices of their businesses, in terms of knowing about the day-to-day and long-term activities of the different hierarchies and functional areas (see Prahalad and Bettis, 1986; Homburg and Pflesser, 2000; Cadogan et al., 2005; Kor and Mesko, 
2013). Indeed, the wine producers within the population of interest were relatively small, meaning that managers were likely to be aware of these firm-level variables.

\section{Sampling frame}

A database was accessed that contained the names and contact details (email addresses) of 687 Canadian wine producers (located throughout the country). These organisations were checked against industry data (Canadian Vintners Association, 2019), revealing that they were all trading entities (highlighting no concerns). Hence, this database was employed as the sampling frame. Please note that while this current investigation makes a unique contribution to the business-to-business marketing literature (via the constructs being tested), this dataset has been utilised in other papers for different purposes.

\section{Field interviews}

To shape the measurement scales used to test the hypothesised and control paths (outlined in a later component of the study), 18 semi-structured interviews were undertaken with owner-managers in several Canadian wine regions (following Katsikeas et al., 2006). These organisations were carefully selected, so that they represented wine producers with different price points, employees (full-time, part-time, and seasonal), degrees of internationalisation, and were located in various clusters ${ }^{2}$ (Charters et al., 2009; Felzensztein and Deans, 2013; Crick and Crick, 2015). These field interviews lasted approximately one hour and explored the multiple forms of coopetition, in terms of whether it exists as an organisation-wide mind-set, or as a set of firm-level behaviours (extending Brandenburger and Nalebuff, 1996; Gnyawali and Park, 2011; McGrath et al., 2019). Context is vital in qualitative research (Granot et al., 2012; reference withheld). Thus, in this current paper, the semi-structured interviews helped to explain the

\footnotetext{
2 Throughout the extant literature, clusters have been investigated in various respects, such as ethnic enclaves (Crick et al., 2016), agricultural regions (Felzensztein et al., 2012), and tourism hotspots (Crick et al., 2018). In this current study, clusters are referred to as geographic regions that contain a group of wine producers - vineyards and wineries (following Felzensztein and Deans, 2013; Felzensztein et al., 2014). In a Canadian context, this included wine clusters, like the Niagara Peninsula in Ontario.
} 
magnitude of coopetition within the Canadian wine sector. For example, in Ontario and Nova Scotia, wine producers actively collaborated with their competitors for mutually-beneficial outcomes. This included informal forms of coopetition, such as sharing equipment and knowledge, as well as more formal strategies, such as engaging in strategic alliances to enter export markets (reinforcing Bengtsson and Kock, 2000; Bouncken et al., 2015; Czakon et al., 2020). However, in British Columbia, these activities were highly-regulated by provincial law.

In other words, wine producers in British Columbia were not allowed to cooperate with their competitors to the same extent as those located in other regions because the provincial government were concerned about potential illicit behaviours, like the formation of monopolies. Interestingly, these firms found it easer to collaborate with their competitors in the United States (e.g., wine producers based in Washington or Oregon), rather than within their own province, or other parts of Canada. This preliminary qualitative data helped to delve deeper into the different forms of coopetition in the Canadian wine industry. Moreover, the 18 field interviews were utilised to explore the relationship between a coopetition-oriented mind-set and coopetition-oriented behaviours under the moderating roles of industry experience and degree of internationalisation. For clarity, these issues were not used to explain the underlying mechanisms behind the statistical results (as per Crick and Crick, 2020; Sraha et al., 2020). Instead, they were used for measurement development purposes (in advance of the quantitative data collection stage) to supplement the review of the pertinent literature (following Katsikeas et al., 2006). The qualitative data were manuallycoded for pre-determined themes - representing the three hypothesised paths (Miles and Huberman, 1994). Then, the constant comparison technique took place, whereby, the interview data (alongside triangulated material, like secondary sources) were analysed for the key similarities and differences between the sampled companies (Suddaby, 2006). In turn, the constant comparison technique identified when a point of theoretical saturation had been reached (guided by Goulding, 2005). This meant that enough qualitative data had been collected, allowing the statistical aspects of the methodology to commence. 


\section{Data collection}

After the 18 field interviews, an electronic survey (designed via Qualtrics) was utilised to test the research hypotheses and control paths. This survey was pre-tested with a sample of knowledgeable academics ( $n$ $=10)$ and practitioners $(n=15)$ to ensure that it was correctly formatted (Reynolds and Diamantopoulos, 1998). The pre-testing stage suggested that there were no problems with the survey. For example, one issue explored the appropriateness of using terms, such as "equipment, etc." in the measurement items for the different forms of coopetition. It was clear that this terminology was understandable to the participants, in which it referred to tangible and intangible assets (similar to Bouncken and Kraus, 2013; Geldes et al., 2015). Then, a pilot study was conducted $(n=30)$, so that the measurement scales could be checked for their descriptive statistics and distributions (Hunt et al., 1982). The pilot study revealed no concerns. Next, the core study was implemented $(n=165)$. Since the operationalisations that were used in the pilot study were identical to those employed within the core study, the two datasets were merged to yield a larger sample size (following Morgan and Hunt, 1994). The final sample $(n=195)$ accounted for a $28.38 \%$ response rate (from a population of 687 businesses), which was deemed to be satisfactory to evaluate the hypothesised and control paths (Keinanen and Kuivalainen, 2015). Moreover, the statistical data were checked for early, vis-à-vis, late response bias by conducting $t$-tests for each construct - showing non-significant differences (Armstrong and Overton, 1977).

\section{Operationalisations}

The constructs within the conceptual framework were operationalised as follows ${ }^{3}$ (Appendix 1 displays the full-list of the multi-item measurement scales). First, a coopetition-oriented mind-set was measured

3 The following construct abbreviations were used - coopetition-oriented mind-set (CM), local-level coopetition (LLC), national-level coopetition (NLC), organisation-level coopetition (OLC), industry experience (INDS), degree of internationalisation (INTL), firm size (SIZE), and firm age (AGE). For statistical purposes, the composite of the three behavioural forms of coopetition was denoted as COOP. In addition, the informant quality scale (INQ) was abbreviated to MARKER because it was employed to test for common method variance under the marker variable technique. That is, despite being 
on a seven-point Likert scale, with six items, ranging from: $1=$ very strongly disagree to $7=$ very strongly agree (adapted from Crick and Crick, 2019). Second, coopetition-oriented behaviours were operationalised through an adapted version of Crick and Crick's (2019) three-component COOP scale. Specifically, local-level coopetition (six items), national-level coopetition (six items), and organisationlevel coopetition (six items) were captured on seven-point Likert scales, ranging from: 1 = very strongly disagree to 7 = very strongly agree. Local-level coopetition concerns cooperation with rivals within a close geographic proximity (Felzensztein and Deans, 2013; Felzensztein et al., 2018), national-level coopetition involves working with industry rivals in different parts of a country (Gnyawali and Park, 2011; Gnyawali and Charleton, 2018), and organisation-level coopetition is collaboration with competitors across different product-markets, regardless of their location (Kock et al., 2010; Crick and Crick, 2016). In this current paper, the COOP scale was adapted from its original form, which used sporting clubs in New Zealand (see Crick and Crick, 2019) to the Canadian wine sector context. The 18 field interviews was one tool to ensure that the measures were appropriate (following Katsikeas et al., 2006).

In this current study, the survey (guided by the field interviews and the pre-testing stage) illustrated that organisation-level coopetition includes business-to-business marketing relationships with non-wine competitors, such as breweries. This was reflected in the instructions for this operationalisation. While coopetition-oriented behaviours have been measured differently throughout the broader business-tobusiness marketing literature (e.g., Luo et al., 2007; Ritala, 2012; Bouncken and Kraus, 2013; Shu et al., 2017; Bouncken et al., 2018; Cui et al., 2018; Estrada and Dong, 2020), the adopted measure could evaluate the propensity of coopetition activities. Third, industry experience was measured using a sliding ratio scale, which asked the respondents for the number of years that they have worked in the global wine sector, ranging from: 0 to 60 years (adapted from Crick and Crick, 2020). Fourth, degree of internationalisation was captured by using the organisations' export ratios, ranging from: 0 to $100 \%$

operationalised as a multi-item variable, the informant quality scale was transformed into a singleindicator because it was only used as a robustness check. 
(following Cadogan et al., 2009). Fifth, firm size was operationalised by the total number of employees seasonal, part-time, and full-time (Peng and Luo, 2000). Sixth, firm age was measured by the number of years that the sampled firms have been trading (Vorhies et al., 2011). Seventh, to measure informant quality, the survey ended with a seven-point Likert scale, with four items, ranging from: 1 = very strongly disagree to 7 = very strongly agree (adapted from Hultman et al., 2009).

Data analysis

The following tools were employed to analyse the statistical data. First, via SPSS 25 , the characteristics of the final sample were examined (Churchill Jr., 1979). This showed that a decent mixture of wine producers participated in this investigation, with a varied number of employees (seasonal, part-time, and full-time), years trading, export activity, and the respondents having different degrees of experience in their organisations and the sector (Table 1). These businesses were located throughout Canada, including larger wine-producing provinces, like Ontario and British Columbia, as well as other regions, such as Alberta and Manitoba. Additionally, these wine producers were all smaller-sized entities, based on their number of full-time employees (Jobber and Shipley, 2012).

[Insert Table 1 about here]

Second, through SPSS 25, an exploratory factor analysis model was produced using a principal components analysis extraction and a varimax rotation (Peterson, 2000; Hsu, 2011). Initially, there were several cross-factor loadings, but after certain problematic indicators were deleted, the items for a coopetition-oriented mind-set, local-level coopetition, national-level coopetition, and organisation-level coopetition loaded onto four factors, with no concerns (Table 2). The Kaiser-Meyer-Olkin (KMO) test of sampling adequacy was satisfactory $(0.94)$, as was the result from Bartlett's test of sphericity $\left(X^{2}=\right.$ $3,851.29 ; d f=78$; Sig. $=0.00$ ). Also, $92.34 \%$ of the overall variance was explained by the exploratory factor analysis model. Critically, the item deletion did not negatively impact the structure of the multi-item measures, but rather, helped to develop strong operationalisations (Jamal and Anastasiadou, 2009). 
[Insert Table 2 about here]

Third, a confirmatory factor analysis model was run via LISREL 9.30 to purify the measurement scales (Cadogan et al., 2005; Jayawardhena, 2010). During this process, the single-item operationalisations for firm size, firm age, industry experience, and degree of internationalisation were transformed through natural logarithms to reduce their variances (Henseler et al., 2016; Xie and Zheng, 2019). The single-item (composite) measure for the informant quality scale was not transformed in this way because the sevenpoint Likert scale (adapted from Hultman et al., 2009) restricted its potential variance. Items were deleted if they had low factor loadings, high error variances, non-significant $t$-values, and issues relating to the modification indices (Gerbing and Anderson, 1988; Steemkamp and Baumgartner, 2000). The final (purified) measures were satisfactory (Table 3). Additionally, the model fit indices of the confirmatory factor analysis were within the minimum thresholds $\left(X^{2}=116.57 ; d f=88 ; x^{2} / d f=1.32 ;\right.$ Sig. $=0.02 ;$ RMSEA $=0.04 ; \mathrm{CFI}=0.99 ; \mathrm{IFI}=0.99 ; \mathrm{NNFI}=0.99 ; \mathrm{GFI}=0.94 ; \mathrm{SRMR}=0.02)$.

[Insert Table 3 about here]

Fourth, using SPSS 25, the research hypotheses and control paths were tested through a six-step hierarchical regression model (Olson et al., 2005). The moderation effects were transformed via residualcentering to alleviate multi-collinearity errors (Echambadi and Hess, 2007). This involved creating composites of the multi-item (and multi-dimensional) measures (following Ping Jr., 1995). Following an earlier point, the single-item measures for the moderators (namely, industry experience and degree of internationalisation) were tested after they were transformed by natural logarithms (as per Henseler et al., 2016; Xie and Zheng, 2019). To present the moderating effects, the results were inputted into a software package which presented the relationships between a coopetition-oriented mind-set and coopetition-oriented behaviours under differing degrees of the interaction variables (following Dawson and Richter, 2006). For clarity, the moderators were not classified as a categorisation of low vs. high (with respective cut-off values), but rather, were examined as impacting the association between the 
independent variable (a coopetition-oriented mind-set) and the outcome variable (coopetition-oriented behaviours) (similar to Cadogan et al., 2009; Shu et al., 2017; Crick and Crick, 2020). The hypothesised and control paths were evaluated during the final stage of the hierarchical regression analysis, since all independent variables were nested within the model (following Cadogan et al., 2012). The change statistics were recorded, alongside the unstandardised regression coefficients $(\beta)$ and $t$-values ${ }^{4}$ (Morgan et al., 2009).

\section{Reliability and validity}

Reliability was assessed by examining the Cronbach's alpha coefficients (a) of the multi-item scales before and after they were purified (all were greater than 0.70) (Churchill Jr., 1979). Face validity was assured by pre-testing the survey with a sample of knowledgeable academics and practitioners (Reynolds and Diamantopoulos, 1998), as well as using an informant quality scale (adapted from Hultman et al., 2009). Content validity was monitored by using operationalisations that were adapted from the extant literature (Peter, 1981; Lapierre, 2000). Convergent validity was evaluated by the final measures having composite reliabilities (CRs) that were well-above 0.60 and average variance extracted values (AVEs) that were in excess of 0.50 (Lin and Huang, 2013; Bottger et al., 2017). To test for discriminant validity, the squared phi matrix correlations (accessed through LISREL 9.30) were compared against the AVEs for each latent variable. Since the largest squared phi matrix correlation $(0.76)$ was less than the lowest

\footnotetext{
${ }^{4}$ Following the recommendation of an anonymous reviewer, to assess the moderating effects in greater depth, the PROCESS macro was used as an extension to SPSS 25 (Hayes, 2018). This involved employing the Johnson-Neyman technique (developed by Johnson and Neyman, 1936) to identify the points on the moderation scales (industry experience and degree of internationalisation) that determine the regions of significance (Spiller et al., 2013). That is, it determined the zones where the respective moderators affect the relationship between the independent variable (a coopetition-oriented mind-set) and the outcome variable (coopetition-oriented behaviours) (Davvetas et al., 2020). Nonetheless, as already noted, the moderating variables were transformed through natural logarithms to reduce their variances (following Henseler et al., 2016; Xie and Zheng, 2019). Henceforth, when using the JohnsonNeyman technique, there is a limited application of the results, since the critical zones will pinpoint to datapoints that are somewhat arbitrary. Consequently, in this current paper, more emphasis was placed on the hierarchical regression analysis to test the moderating effects (see Olson et al., 2005; Morgan et al., 2009).
} 
AVE (0.83), discriminant validity is highly-likely to exist (Fornell and Larcker, 1981). Table 4 displays the final scale reliabilities and the discriminant validity test.

[Insert Table 4 about here]

\section{Common method variance}

Common method variance was evaluated by designing the survey in a way that made it as short and interactive as possible for the respondents - to maximise their engagement with the questions and to minimise their fatigue (Podsakoff et al., 2003; Pehrsson, 2014). Then, using SPSS 25, the marker variable technique was employed as follows. First, a construct that was theoretically-unrelated to any other latent variable within the conceptual framework was selected, namely, the informant quality scale (adapted from Hultman et al., 2009). Second, a bivariate correlation matrix was produced, containing all constructs that were used to test the hypothesised and control paths. Third, a partial correlation matrix was created, with the same latent variables, but controlling for the marker variable. Fourth, the differences between the two correlation matrices were averaged. Since the average difference was very small $(r=0.00)$, it is anticipated that the statistical data were not biased by a common method factor (Lindell and Whitney, 2001). In addition, the informant quality scale had a reasonably large variance (0.62), allowing it to be utilised as the marker variable. The statistical results follow in the next section.

\section{Results}

Before the research hypotheses and control paths were tested, the bivariate correlations (and their descriptive statistics) showed the underlying relationships between the constructs within the conceptual framework (Table 5).

\section{[Insert Table 5 about here]}

Turning to the hierarchical regression analysis, a coopetition-oriented mind-set had a positive and significant relationship with coopetition-oriented behaviours $(\beta=0.57 ; t=11.16)$. As such, $\mathrm{H} 1$ was 
supported ${ }^{5}$. Surprisingly, industry experience negatively moderated the link between a coopetitionoriented mind-set and coopetition-oriented behaviours $(\beta=-0.06 ; t=-1.82)$. Hence, a counter-intuitive result was found for $\mathrm{H} 2$. Alternatively, degree of internationalisation yielded a positive moderating effect $(\beta=0.05 ; t=2.14)$. Thus, support existed for $\mathrm{H} 3$. Furthermore, the Johnson-Neyman technique showed that when industry experience exceeds 2.89 , the moderating effect becomes negative and significant ( $p$ $<0.01)$. When degree of internationalisation surpasses 1.35 , the interaction effect becomes positive and significant $(p<0.01)$. Regarding the control paths, firm size was positively and significantly related to coopetition-oriented behaviours $(\beta=0.21 ; t=4.27)$, whereas, firm age produced a negative, but nonsignificant path $(\beta=-0.12 ; t=-1.17)$. Moreover, during the final (nested) stage of the hierarchical regression analysis, the $\Delta R^{2}(0.01)$, relative to the $\Delta F(4.58)$, was significant $(p<0.05)$ - providing additional statistical reinforcement for the hypothesised and control paths (Table 6). Likewise, the adjusted $\mathrm{R}^{2}$ indicated that the independent variables explained $81 \%$ of the variance of coopetitionoriented behaviours (the outcome variable). These results are discussed in the next section.

\section{[Insert Table 6 about here]}

\section{Discussion}

Prior to this investigation, coopetition-oriented behaviours had been relatively well-studied throughout the broader business-to-business marketing literature (Bengtsson and Kock, 2000; Luo et al., 2007; Rusko, 2011; Felzensztein et al., 2012; Bouncken and Kraus, 2013; Park et al., 2014; Bengtsson and Raza-Ullah, 2016; Granata et al., 2018; Crick, 2020; Yan et al., 2020). Scholars had found that by engaging in

\footnotetext{
${ }^{5}$ To emphasise an important point, the positive and significant path between a coopetition-oriented mindset and coopetition-oriented behaviours was tested at an aggregate-level. That is, the coopetitionoriented behaviours construct (COOP) was comprised of three behavioural forms. Nonetheless, at an aggregate-level, there was a positive and significant correlation between a coopetition-oriented mind-set and coopetition-oriented behaviours $(r=0.82 ; p<0.01)$. Likewise, the facets of the three-component COOP scale showed positive and significant correlations. That is, local-level coopetition $(r=0.79 ; p<$ 0.01 ), national-level coopetition ( $r=0.64 ; p<0.01)$, and organisation-level coopetition $(r=0.83 ; p<0.01)$. The author expresses gratitude to an anonymous reviewer for requesting extra clarity on this point.
} 
behavioural forms of coopetition (e.g., resource and capability-sharing activities), organisations can learn new ways to survive and grow within their competitive business environments (Bengtsson and Kock, 2014; Geldes et al., 2015; Bengtsson et al., 2016; Hannah and Eisenhardt, 2018; Leite et al., 2018; Basterretxea et al., 2019; Czakon et al., 2020). Hence, there is a considerable body of knowledge pertaining to the coopetition - company performance relationship (e.g., Rich, 2003; Rindfleisch and Moorman, 2003; Ritala, 2012; Shu et al., 2017; Bouncken et al., 2018; Crick, 2019; Estrada and Dong, 2020). That said, there are some pertinent research gaps surrounding the drivers of coopetition activities. Specifically, although a coopetition-oriented mind-set is likely to manifest into coopetition-oriented behaviours (Brandenburger and Nalebuff, 1996; Gnyawali and Park, 2011; Bouncken et al., 2018; Crick and Crick, 2019), the nature of this association remains under-researched. That is, it is unclear whether industry experience and degree of internationalisation are mechanisms that help decision-makers to harness their assumptions, values, and beliefs about cooperating with rival entities (to engage in coopetition strategies).

Henceforth, guided by resource-based theory and the relational view (Barney, 1991; Dyer and Singh, 1998; Coviello and Brodie, 2001; Lavie, 2006; Dyer et al., 2018), this current paper unpacked the relationship between a coopetition-oriented mind-set and coopetition-oriented behaviours under the moderating roles of industry experience and degree of internationalisation. From an empirical study, the following key findings contribute to the business-to-business marketing literature. First, a coopetitionoriented mind-set was found to serve as an antecedent of coopetition-oriented behaviours (supporting Gnyawali and Park, 2011; Crick, 2018; Crick and Crick, 2019). Mind-sets have been studied as a vital component of corporate cultures, since they determine the issue(s) that managers and functional-level employees believe to be important (Prahalad and Bettis, 1986; Kor and Mesko, 2013). In fact, organisation-wide mind-sets are likely to manifest into firm-level behaviours that match the issue that is assumed, valued, and believed to be a critical driver of company performance - as per the earlier example of market-oriented mind-sets having a positive association with market-oriented behaviours (see 
Homburg and Pflesser, 2000). Since limited research surrounds the antecedents of coopetition-oriented behaviours (Bengtsson and Raza-Ullah, 2016; Gnyawali and Charleton, 2018; Hoffmann et al., 2018; Czakon et al., 2020), new evidence has emerged on how a coopetition-oriented mind-set should lead to firms implementing coopetition strategies (as per Brandenburger and Nalebuff, 1996; Bouncken et al., 2015; McGrath et al., 2019).

Second, a more novel contribution relates to the moderating factors. Put another way, the link between a coopetition-oriented mind-set and coopetition-oriented behaviours has been examined in earlier research (Gnyawali and Park, 2011; Bouncken et al., 2015; McGrath et al., 2019). Yet, to explore the moderating effects on this relationship, the main (direct) path needed to be conceptualised and tested. The extant literature suggests that if firms possess sector-level knowledge of their competitors' activities (as well as their strengths and weaknesses), they can utilise this industry experience to engage in effective forms of coopetition - to obtain mutually-beneficial outcomes (Felzensztein and Deans, 2013; Geldes et al., 2017). That is, coopetition can lead to various negative consequences, such as tensions (e.g., conflict, power imbalances, and opportunistic behaviours), lost intellectual property, and diluted competitive advantages (Luo et al., 2007; Ritala and Hurmelinna-Laukkanen, 2013; Raza-Ullah et al., 2014; Bouncken et al., 2018; Crick et al., 2021). Thus, it was anticipated that industry experience could help organisations to be more selective of which rivals that they collaborate with, in terms of working with competing entities that they can trust and will not harm their performance (Tidstrom, 2014; Czakon and Czernek, 2016; Ryan et al., 2019; Lascaux, 2020). Yet, industry experience negatively moderated the link between a coopetitionoriented mind-set and coopetition-oriented behaviours (Figure 2). This surprising result could be explained by industry experience discouraging companies from collaborating with their competitors, in terms of making them aware of the risks of coopetition strategies (Tidstrom, 2009; Bouncken and Kraus, 2013; Mattsson and Tidstrom, 2015; Tidstrom et al., 2018; Crick, 2020).

[Insert Figure 2 about here] 
Following on, it could be that more experienced companies (that know the dynamics of their sector) decide that there are more risks than rewards of engaging in coopetition-oriented behaviours - meaning that they choose to compete under an individualistic business model to avoid some of the dark-sides that coopetition activities might yield (building upon Luo et al., 2007; Cui et al., 2018; Czakon et al., 2020). Indeed, more experienced organisations may not need to engage in coopetition, since they might have the resources and capabilities that are required to survive and grow within their competitive business environments (Bengtsson et al., 2016; Granata et al., 2018; McGrath et al., 2019). That is, experienced firms could be familiar with ways to create value for customers and operate efficiently that means that they do not depend on borrowing assets from industry rivals ${ }^{6}$ (Rindfleisch and Moorman, 2003; Crick, 2018). Third, degree of internationalisation positively moderated the relationship between a coopetitionoriented mind-set and coopetition-oriented behaviours (supporting Kock et al., 2010; Felzensztein et al., 2014; Shu et al., 2017; Ryan et al., 2019). This result indicates that internationalised firms have an incentive to collaborate with competing entities due to potential benefits, like increased sales, superior brand equity, and efficient supply chains (see Smith et al., 2003; Cadogan et al., 2009; Faroque et al., 2017; Nordin and Lindbergh, 2019). The positive moderation effect (Figure 3) suggests that if firms are targeting overseas markets, they are likely to recognise that coopetition could help them to be more successful in such arenas (complementing their coopetition-oriented mind-sets).

\section{[Insert Figure 3 about here]}

In turn, a coopetition-oriented mind-set, combined with higher-degrees of internationalisation, should positively impact coopetition-oriented behaviours. This finding contributes to the limited volume of

\footnotetext{
${ }^{6}$ An anonymous reviewer raised the issue of assessing whether a manager's age has a moderating role in the link between a coopetition-oriented mind-set and coopetition-oriented behaviours. For instance, younger managers, with lower-levels of industry experience, might be more proactive to engage in coopetition as a potentially performance-enhancing business-to-business marketing strategy. This is through younger managers being eager to experiment with new approaches to be more successful within their markets. Unfortunately, data were not collected on the respondents' ages (just the firm age variable), meaning that issue (albeit interesting) could not be evaluated. Yet, this anonymous reviewer's comment was appreciated and could be tested in future research.
} 
research surrounding coopetition in an international arena. Instead of focusing on large corporations involved in strategies alliances (e.g., Luo, 2005; Luo and Tung, 2007; Robson et al., 2012; Liu et al., 2019), stronger insights have emerged on how smaller-sized businesses engage in international forms of coopetition (extending Kock et al., 2010; Faroque et al., 2017; Shu et al., 2017; Ryan et al., 2019). For example, it suggests that internationalised organisations should foster a coopetition-oriented mind-set because it may assist them to collaborate with their competitors (extending Bouncken et al., 2015; McGrath et al., 2019). In fact, it signifies that firms with an internationalised business model are more likely to implement coopetition strategies than those focused on domestic markets (building upon Luo, 2005; Felzensztein et al., 2014; Crick and Crick, 2020). Fourth, by investigating the nature of the link between a coopetition-oriented mind-set and coopetition-oriented behaviours, stronger evidence has emerged on the different forms of coopetition activities. That is, when coopetition was incorporated into the business-to-business marketing literature, there were two schools-of-thought. On the one hand, Brandenburger and Nalebuff (1996) argued that coopetition exists as an organisation-wide mind-set pertaining to managers and functional-level employees believing in the importance of cooperating with industry rivals. On the other hand, Bengtsson and Kock (1999) found that coopetition is a business-tobusiness marketing strategy (or set of firm-level behaviours) surrounding the interplay between cooperation and competition.

The latter viewpoint has been more commonly-studied throughout the broader business-to-business marketing literature (see Bengtsson and Kock, 2000; Rusko, 2011; Felzensztein et al., 2012; Park et al., 2014; Bengtsson and Raza-Ullah, 2016; Gnyawali et al., 2016; Leite et al., 2018; Czakon et al., 2020). By finding that there is a positive link between a coopetition-oriented mind-set and coopetition-oriented behaviours (moderated in varied capacities by industry experience and degree of internationalisation), new evidence has emerged on the different ways that coopetition can be implemented (bridging the gap between Brandenburger and Nalebuff, 1996; Bengtsson and Kock, 1999). This was achieved by connecting coopetition-oriented behaviours to the lesser-known form of coopetition surrounding 
organisation-wide mind-sets (extending Gnyawali and Park, 2011; Bouncken et al., 2015; Crick, 2018; Gnyawali and Charleton, 2018). On that note, a growing body of knowledge surrounds coopetition being a multi-level construct, in which firms can collaborate with their competitors across different geographic proximities and between product-markets (Kock et al., 2010; Raza-Ullah et al., 2014; Bengtsson and Raza-Ullah, 2016; Felzensztein et al., 2018; Crick and Crick, 2019). This current investigation expands upon these conceptualisations to evaluate how coopetition-oriented mind-sets and coopetition-oriented behaviours (specifically, local-level coopetition, national-level coopetition, and organisation-level coopetition) serve as different forms/levels of this multi-faceted variable.

Fifth, turning to the control variables, firm size had a positive and significant relationship with coopetitionoriented behaviours. This result reinforces earlier papers, which have found that larger businesses, with a greater volume of resources and capabilities, have increased scope to engage in coopetition strategies (e.g., Rusko, 2011; Park et al., 2014; Czakon and Czernek, 2016). Interestingly, firm age had a negative, but non-significant path. This finding suggests that older organisations do not have any advantage over younger entities at engaging in coopetition (challenging Bengtsson et al., 2016; Crick, 2018; Lascaux, 2020). Hence, it is important that organisations (especially those with an internationalised business model) possess a coopetition-oriented mind-set to engage in coopetition strategies. Sixth, a final discussion point is that by integrating resource-based theory and the relational view, this paper was able to evaluate the cooperative and competitive aspects of coopetition-oriented mind-sets and coopetitionoriented behaviours (Lavie, 2006; Dyer et al., 2018; Crick, 2019). While the resource-based view could explain the ways that firms share resources and capabilities with their rivals (O'Dwyer et al., 2011; Bouncken et al., 2015; Hannah and Eisenhardt, 2018), the relational view was incorporated to explore the collaborative aspects of these business-to-business marketing strategies (Hunt and Derozier, 2004; Barney, 2018; Crick, 2020). It shows that although the resource-based view explains how businesses share tangible and intangible assets with their competitors in coopetition strategies (Hannah and 
Eisenhardt, 2018; Gnyawali and Charleton, 2018), the relational view accounts for the importance of highquality inter-firm relationships (Dyer and Singh, 1998; Crick, 2019). This article is concluded as follows.

\section{Conclusions}

Summary

Guided by resource-based theory and the relational view, the objective of this current study was to evaluate the relationship between a coopetition-oriented mind-set and coopetition-oriented behaviours under the moderating roles industry experience and degree of internationalisation. To achieve this research objective, after undertaking 18 field interviews, survey data were collected from a nation-wide sample of 195 Canadian wine producers. After checking the statistical data for all major assessments of reliability and validity (together with common method variance), the following four conclusions are made. First, it is concluded that a coopetition-oriented mind-set has a positive relationship with coopetitionoriented behaviours. Second, another conclusion is that industry experience negatively moderates the link between a coopetition-oriented mind-set and coopetition-oriented behaviours, whereas, degree of internationalisation yields a positive moderation effect. Third, following on, a related conclusion is that coopetition is a multi-faceted variable. That is, there are various ways that companies can be involved with this business-to-business marketing construct, namely, as an organisation-wide mind-set and/or a set of firm-level behaviours. Fourth, it finally concluded that by integrating resource-based theory with the relational view, the cooperative and competitive aspects of coopetition activities (in these different forms) can be better-understood.

\section{Managerial recommendations}

In addition to its theoretical contribution, this article offers the following managerial recommendations. First, there are certain advantages of fostering a coopetition-oriented mind-set - not least of which how they help companies to engage in coopetition strategies. Specifically: 
- If decision-makers possess assumptions, values, and beliefs about the importance of cooperating with their competitors, they should harness them to engage in behavioural forms of coopetition (e.g., resource and capability-sharing activities).

- To do this, managers and functional-level employees should trust their instincts about the value of coopetition strategies and attempt to collaborate with certain industry rivals (namely, those that are trustworthy and target similar product-markets) for mutually-beneficial outcomes.

Second, while a coopetition-oriented mind-set can help businesses to implement coopetition activities, there are some factors (focusing on industry experience and degree of internationalisation) that might help or hinder these strategies. Consequently:

- If companies have accumulated knowledge of their rivals' strengths and weaknesses (and their key strategies), this industry experience could save them from working with untrustworthy competitors that might harm their performance.

- Internationalised firms should recognise that coopetition activities can help them to be more successful in their overseas markets. Thus, they should foster their coopetition-oriented mindsets to share resources and capabilities with complementary rival entities.

Third, organisations must acknowledge that coopetition-oriented behaviours are comprised of collaborative and rivalrous dimensions. This means that in coopetition strategies, there will always be some degree of competitive rivalry, regardless of the magnitude of resource and capability-sharing activities. Henceforth:

- If companies share resources and capabilities with their coopetition partners, they should never forget that these entities are their competitors, for which caution must be exercised to avoid negative outcomes, like tensions (e.g., conflict, power imbalances, and opportunistic behaviours), lost intellectual property, and diluted competitive advantages. 
- If businesses do not engage in coopetition partnerships (discouraged by their industry experience), they might be disadvantaged by missing out on certain resources, capabilities, and opportunities that might improve their performance.

In short, decision-makers should utilise these managerial recommendations to effectively foster their coopetition-oriented mind-sets into behavioural forms of coopetition. This involves managing the correct forms of industry experience and degrees of internationalisation.

\section{Limitations and avenues for future research}

While this current study has contributed to the business-to-business marketing literature, there are certain limitations that can be addressed in future research. First, the empirical context was the Canadian wine industry. Although this sector hosted high-degrees of cooperativeness and competitiveness (ideal for studying coopetition), as well as internationalised companies, it was just one setting. Consequently, future research should build upon this paper by sampling multiple industries to yield generalisable results. Second, although a decent response rate was obtained (28.38\%), the final sample size was relatively small $(n=195)$. Therefore, if scholars build upon this investigation, they should attempt to collect larger volumes of data to make stronger conclusions. Third, other than the 18 field interviews, the statistical data originated from a single-source survey. If possible, future research should utilise a combination of primary and secondary data, such as measuring certain constructs through archival sources (e.g., firm size and firm age). Fourth, despite the data being checked for all major forms of reliability and validity (including common method variance), endogeneity bias was not considered. As such, these tests should be conducted (using appropriate instrumental variables) in future investigations to assess the potential for correlated error terms. In closing, these limitations do not pose serious concerns, but instead, provide several directions for future research. 


\section{References}

Acquaah, M. (2007), "Managerial social capital, strategic orientation, and organizational performance in an emerging economy", Strategic Management Journal, Vol. 28 No. 12, pp. 1235-1255.

Armstrong, J.S. and Overton, T.S. (1977), "Estimating non-response bias in mail surveys", Journal of Marketing Research, Vol. 14 No. 3, pp. 396-402.

Barney, J.B. (1991), "Firm resources and sustained competitive advantage", Journal of Management, Vol. 17 No. 1, pp. 99-120.

Barney, J.B. (2001), "Resource-based theories of competitive advantage: a ten-year retrospective on the resource-based view", Journal of Management, Vol. 27 No. 6, pp. 643-650.

Barney, J.B. (2018), "Why resource-based theory's model of profit appropriation must incorporate a stakeholder perspective", Strategic Management Journal, Vol. 39 No. 13, pp. 3305-3325.

Barney, J.B., Ketchen Jr., D.J. and Wright, M. (2011), "The future of resource-based theory: revitalization or decline?", Journal of Management, Vol. 37 No. 5, pp. 1299-1315.

Basterretxea, I., Charterina, J. and Landeta, J. (2019), "Coopetition and innovation: lessons from worker cooperatives in the Spanish machine tool industry", Journal of Business \& Industrial Marketing, Vol. 34 No. 6, pp. 1223-1235.

Bel, R. (2018), "A property rights theory of competitive advantage", Strategic Management Journal, Vol. 39 No. 6, pp. 1678-1703.

Bengtsson, M. and Kock, S. (1999), "Cooperation and competition in relationships between competitors in business networks", Journal of Business \& Industrial Marketing, Vol. 14 No. 3, pp. 178-194.

Bengtsson, M. and Kock, S. (2000), "Coopetition in business networks: to cooperate and compete simultaneously", Industrial Marketing Management, Vol. 29 No. 5, pp. 411-426.

Bengtsson, M. and Kock, S. (2014), "Coopetition - quo vadis? Past accomplishments and future challenges", Industrial Marketing Management, Vol. 43 No. 2, pp. 180-188.

Bengtsson, M. and Raza-Ullah, T. (2016), "A systematic review of research on coopetition: toward a multilevel understanding", Industrial Marketing Management, Vol. 57 No. 1, pp. 23-39.

Bengtsson, M., Raza-Ullah, T. and Vanyushyn, V. (2016), "The coopetition paradox and tension: the moderating role of coopetition capability", Industrial Marketing Management, Vol. 53 No. 1, pp. 1930 .

Bottger, T., Rudolph, T., Evanschitzky, H. and Pfrang, T. (2017), "Customer inspiration: conceptualization, scale development, and validation”, Journal of Marketing, Vol. 81 No. 6, pp. 116131.

Bouncken, R.B. and Kraus, S. (2013), "Innovation in knowledge-intensive industries: the double-edged sword of coopetition", Journal of Business Research, Vol. 66 No. 10, pp. 2060-2070.

Bouncken, R.B., Fredrich, V., Ritala, P. and Kraus, S. (2018), "Coopetition in new product development alliances: advantages and tensions for incremental and radical innovation", British Journal of Management, Vol. 29 No. 3, pp. 391-410.

Bouncken, R.B., Gast, J., Kraus, S. and Bogers, M. (2015), "Coopetition: a systematic review, synthesis, and future research directions", Review of Managerial Science, Vol. 9 No. 3, pp. 577-601. 
Brandenburger, A.M. and Nalebuff, B.J. (1996), Co-opetition, Doubleday Dell Publishing Group Inc., New York: NY.

Brennan, R., Canning, L. and McDowell, R. (2017), Business-to-Business Marketing, fourth edition, Sage Publications Limited, London, United Kingdom.

Cadogan, J.W., Kuivalinen, O. and Sundqvist, S. (2009), "Export market-oriented behavior and export performance: quadratic and moderating effects under differing degrees of market dynamism and internationalization", Journal of International Marketing, Vol. 17 No. 4, pp. 71-89.

Cadogan, J.W., Sundqvist, S., Puumalainen, K. and Salminen, R.T. (2012), "Strategic flexibilities and export performance: the moderating roles of export market-oriented behavior and the export environment", European Journal of Marketing, Vol. 46 No. 10, pp. 1418-1452.

Cadogan, J.W., Sundqvist, S., Salminen, R.T. and Puumalainen, K. (2005), "Export marketing, interfunctional interactions, and performance consequences", Journal of the Academy of Marketing Science, Vol. 33 No. 4, pp. 520-535.

Canadian Vintners Association. (2019), "Industry statistics", retrieved from: https://www.canadianvintners.com/industry-statistics/ [accessed 29.10.2019].

Carbonell, P. and Escudero, A.I.R. (2010), "The effect of market orientation on innovation speed and new product performance”, Journal of Business \& Industrial Marketing, Vol. 25 No. 7, pp. 501-513.

Charters, S., Fountain, J. and Fish, N. (2009), "You felt like lingering: experiencing real service at the winery tasting room", Journal of Travel Research, Vol. 48 No. 1, pp. 122-134.

Churchill Jr., G.A. (1979), "A paradigm for developing better measures of marketing constructs", Journal of Marketing Research, Vol. 16 No. 1, pp. 64-73.

Conner, K.R. and Prahalad, C.K. (1996), "A resource-based theory of the firm: knowledge versus opportunism", Organization Science, Vol. 7 No. 5, pp. 477-501.

Cortez, R.M. and Johnston, W.J. (2019), "Marketing role in B2B settings: evidence from advanced, emerging and developing markets", Journal of Business \& Industrial Marketing, Vol. 34 No. 3, pp. 605-617.

Coviello, N.E. and Brodie, R.J. (2001), "Contemporary marketing practices of consumer and businessto-business firms: how different are they?", Journal of Business \& Industrial Marketing, Vol. 16 No. 5, pp. 382-400.

Crick, D. (2007), "UK SMEs' motives for internationalizing: differences between firms employing particular overseas market servicing strategies", Journal of International Entrepreneurship, Vol. 5 Nos. 1/2, pp. 11-23.

Crick, D. and Crick, J.M. (2015), "Learning and decision making in marketing planning: a study of New Zealand vineyards", Marketing Intelligence \& Planning, Vol. 33 No. 5, pp. 707-732.

Crick, D. and Crick, J.M. (2016), "Coopetition at the sports marketing/entrepreneurship interface: a case study of a Taekwondo organisation”, Marketing Intelligence \& Planning, Vol. 34 No. 2, pp. 169-187.

Crick, D., Chaudhry, S. and Crick, J.M. (2016), "Trading in a competitive environment: South-Asian restaurants in the UK", Strategic Change, Vol. 25 No. 4, pp. 371-382.

Crick, D., Chaudhry, S. and Crick, J.M. (2018), "Risks/rewards and an evolving business model: a case study of a small lifestyle business in the UK tourism sector", Qualitative Market Research: An International Journal, Vol. 21 No. 2, pp. 143-165. 
Crick, J.M. (2018), "The facets, antecedents and consequences of coopetition: an entrepreneurial marketing perspective", Qualitative Market Research: An International Journal, Vol. 21 No. 2, pp. 253-272.

Crick, J.M. (2019), "Moderators affecting the relationship between coopetition and company performance", Journal of Business \& Industrial Marketing, Vol. 34 No. 2, pp. 518-531.

Crick, J.M. (2020), "The dark-side of coopetition: when collaborating with competitors is harmful for company performance", Journal of Business \& Industrial Marketing, Vol. 35 No. 2, pp. 318-337.

Crick, J.M. and Crick, D. (2019), "Developing and validating a multi-dimensional measure of coopetition", Journal of Business \& Industrial Marketing, Vol. 34 No. 4, pp. 665-689.

Crick, J.M. and Crick, D. (2020), "The Yin and Yang nature of coopetition activities: non-linear effects and the moderating role of competitive intensity for internationalised firms", International Marketing Review (forthcoming).

Crick, J.M., Crick, D. and Chaudhry, S. (2020), "Entrepreneurial marketing decision-making in rapidly internationalising and de-internationalising start-up firms", Journal of Business Research, Vol. 113 No. 1, pp. 158-167.

Crick, J.M., Crick, D. and Chaudhry, S. (2021), "The dark-side of coopetition: it's not what you say, but the way that you do it", Journal of Strategic Marketing (forthcoming).

Cui, V., Yang, H. and Vertinsky, I. (2018), "Attacking your partners: strategic alliances and competition between partners in product-markets", Strategic Management Journal, Vol. 39 No. 12, pp. 31163139 .

Czakon, W. and Czernek, K. (2016), "The role of trust-building mechanisms in entering into network coopetition: the case of tourism networks in Poland", Industrial Marketing Management, Vol. 57 No. 1, pp. 64-74.

Czakon, W., Srivastava, M.K., Le Roy, F. and Gnyawali, D.R. (2020), "Coopetition strategies: critical issues and research directions", Long Range Planning (forthcoming).

Davvetas, V., Diamantopoulos, A. and Liu, L. (2020), "Lit up or dimmed down? Why, when, and how regret anticipation affects consumers' use of the global brand halo", Journal of International Marketing (forthcoming).

Dawson, J.F. and Richter, A.W. (2006), "Probing three-way interactions in moderated multiple regression: development and application of a slope difference test", Journal of Applied Psychology, Vol. 91 No. 4, pp. 917-926.

Day, G.S. (2014), "An outside-in approach to resource-based theories", Journal of the Academy of Marketing Science, Vol. 42 No. 1, pp. 27-28.

Dobrucali, B. (2020), "The role of Guanxi on international business-to-business relationships: a systematic review and future directions", Journal of Business \& Industrial Marketing (forthcoming).

Dyer, J.H. and Singh, H. (1998), "The relational view: cooperative strategy and sources of interorganizational competitive advantage", Academy of Management Review, Vol. 23 No. 4, pp. 660679 .

Dyer, J.H., Singh, H. and Hesterly, W.S. (2018), "The relational view revisited: a dynamic perspective on value creation and value capture", Strategic Management Journal, Vol. 39 No. 12, pp. 3140-3162. 
Echambadi, R. and Hess, J.D. (2007), "Mean-centering does not alleviate collinearity problems in moderated multiple regression models", Marketing Science, Vol. 26 No. 3, pp. 438-445.

Estrada, I. and Dong, J.Q. (2020), "Learning from experience? Technological investments and the impact of coopetition experience on firm profitability", Long Range Planning (forthcoming).

Faroque, A.R., Morrish, S.C. and Ferdous, A.S. (2017), "Networking, business process innovativeness and export performance: the case of South Asian low-tech industry", Journal of Business \& Industrial Marketing, Vol. 32 No. 6, pp. 864-875.

Felzensztein, C. and Deans, K.R. (2013), "Marketing practices in wine clusters: insights from Chile", Journal of Business \& Industrial Marketing, Vol. 28 No. 4, pp. 357-367.

Felzensztein, C., Gimmon, E. and Aqueveque, C. (2012), "Clusters or un-clustered industries? Where inter-firm marketing cooperation matters", Journal of Business \& Industrial Marketing, Vol. 27 No. 5 , pp. 392-402.

Felzensztein, C., Gimmon, E. and Deans, K.R. (2018), "Coopetition in regional clusters: keep calm and expect unexpected changes", Industrial Marketing Management, Vol. 69 No. 1, pp. 116-124.

Felzensztein, C., Stringer, C., Benson-Rea, M. and Freeman, S. (2014), "International marketing strategies in industrial clusters: insights from the Southern Hemisphere", Journal of Business Research, Vol. 67 No. 5, pp. 837-846.

Finch, J., Wagner, B. and Hynes, N. (2012), "Resources prospectively: how actors mobilize resources in business settings", Journal of Business Research, Vol. 65 No. 2, pp. 164-174.

Fornell, C. and Larcker, D.F. (1981), "Structural equation models with unobservable variables and measurement error: algebra and statistics", Journal of Marketing Research, Vol. 18 No. 3, pp. $382-$ 388.

Frisillo, D. (2007), "An analysis of a potential cluster in an energy sector of Albany, NY", Journal of Business \& Industrial Marketing", Vol. 22 No. 7, pp. 508-516.

Geldes, C., Felzensztein, C., Turkina, E. and Durand, A. (2015), "How does proximity affect inter-firm marketing cooperation? A study of an agribusiness cluster", Journal of Business Research, Vol. 68 No. 2, pp. 263-272.

Geldes, C., Heredia, J., Felzensztein, C. and Mora, M. (2017), "Proximity as determinant of business cooperation for technological and non-technological innovations: a study of an agribusiness cluster", Journal of Business \& Industrial Marketing, Vol. 32 No. 1, pp. 167-178.

Gerbing, D.W. and Anderson, J.C. (1988), "An updated paradigm for scale development: incorporating uni-dimensionality and its assessment", Journal of Marketing Research, Vol. 25 No. 2, pp. 186-192.

Gnyawali, D.R. and Park, B.J.R. (2011), "Coopetition between giants: collaboration with competitors for technological innovation”, Research Policy, Vol. 40 No. 5, pp. 650-663.

Gnyawali, D.R. and Charleton, T.R. (2018), "Nuances in the interplay of competition and cooperation: towards a theory of coopetition", Journal of Management, Vol. 44 No. 7, pp. 2511-2534.

Gnyawali, D.R., Madhavan, R., He, J. and Bengtsson, M. (2016), "The competition-cooperation paradox in inter-firm relationships: a conceptual framework", Industrial Marketing Management, Vol. 53 No. 1, pp. 7-18. 
Goulding, C. (2005), "Grounded theory, ethnography and phenomenology: a comparative analysis of three qualitative strategies for marketing research", European Journal of Marketing, Vol. 39 Nos. 3/4, pp. 294-308.

Granata, J., Lasch, F., Le Roy, F. and Dana, L-P. (2018), "How do micro-firms manage coopetition? A study of the wine sector in France", International Small Business Journal, Vol. 36 No. 3, pp. 331 355.

Granot, E., Brashear, T.G. and Motta, P.C. (2012), "A structural guide to in-depth interviewing in business and industrial marketing research", Journal of Business \& Industrial Marketing, Vol. 27 No. 7, pp. 547-553.

Hamzah, M.I., Othman, A.K. and Hassan, F. (2020), "Mediating effects of individual market orientation on the link between learning orientation and job performance", Journal of Business \& Industrial Marketing, Vol. 35 No. 4, pp. 655-668.

Hannah, D.P. and Eisenhardt, K.M. (2018), "How firms navigate cooperation and competition in nascent ecosystems", Strategic Management Journal, Vol. 39 No. 12, pp. 3163-3192.

Haynes, A.F. (2018), Introduction to Mediation, Moderation, and Conditional Process Analysis, second edition, Guildford Press, New York: NY.

Henseler, J., Ringle, C.M. and Sarstedt, M. (2016), "Testing measurement invariance of composites using partial least squares", International Marketing Review, Vol. 33 No. 3, pp. 405-431.

Hoffmann, W., Lavie, D., Reuer, J.J. and Shiplov, A. (2018), "The interplay of competition and cooperation”, Strategic Management Journal, Vol. 39 No. 12, pp. 3033-3052.

Holmlund, M. (2004), "Analyzing business relationships and distinguishing different interaction levels", Industrial Marketing Management, Vol. 33 No. 4, pp. 279-287.

Homburg, C. and Pflesser, C. (2000), "A multiple-layer model of market-oriented organizational culture: measurement issues and performance outcomes", Journal of Marketing Research, Vol. 37 No. 4, pp. 449-462.

Hsu, Y. (2011), "Design innovation and marketing strategy in successful product competition", Journal of Business \& Industrial Marketing, Vol. 26 No. 4, pp. 223-236.

Hultman, M., Robson, M.J. and Katsikeas, C.S. (2009), "Export product strategy fit and performance: an empirical investigation", Journal of International Marketing, Vol. 17 No. 4, pp. 1-23.

Hunt, S.D. and Derozier, C. (2004), "The normative imperatives of business and marketing strategy: grounding strategy in resource-advantage theory", Journal of Business \& Industrial Marketing, Vol. 19 No. 1 , pp. 5-22.

Hunt, S.D. and Morgan, R.M. (1995), "The comparative advantage theory of competition", Journal of Marketing, Vol. 59 No. 2, pp. 1-15.

Hunt, S.D., Sparkman Jr., R.D. and Wilcox, J.B. (1982), "The pre-test in survey research: issues and preliminary findings", Journal of Marketing Research, Vol. 19 No. 2, pp. 269-273.

Jamal, A. and Anastasiadou, K. (2009), "Investigating the effects of service quality dimensions and expertise on loyalty", European Journal of Marketing, Vol. 43 Nos. 3/4, pp. 398-420.

Jaworski, B.J. and Kohli, A.K. (1993), "Market orientation: antecedents and consequences", Journal of Marketing, Vol. 57 No. 3, pp. 53-70. 
Jayawardhena, C. (2010), "The impact of service encounter quality in service evaluation: evidence from a business-to-business context", Journal of Business \& Industrial Marketing, Vol. 25 No. 2, pp. 338348.

Jobber, D. and Shipley, D. (2012), "Marketing-orientated pricing", European Journal of Marketing, Vol. 46 Nos. 11/12, pp. 1647-1670.

Johnson, J.L., Martin, K.D. and Saini, A. (2012), "The role of a firm's strategic orientation dimensions in determining market orientation”, Industrial Marketing Management, Vol. 41 No. 4, pp. 715-724.

Johnson, P.O. and Neyman, J. (1936), "Tests of certain linear hypotheses and their application to some educational problems", Statistical Research Memoirs, Vol. 1 No. 1, pp. 57-93.

Katsikeas, C.S., Morgan, N.A., Leonidou, L.C. and Hult, G.T.M. (2016), "Assessing performance outcomes in marketing", Journal of Marketing, Vol. 80 No. 2, pp. 1-20.

Katsikeas, C.S., Samiee, S. and Theodosiou, M. (2006), "Strategy fit and performance consequences of international marketing standardization", Strategic Management Journal, Vol. 27 No. 9, pp. 867-890.

Keinanen, H. and Kuivalainen, O. (2015), "Antecedents of social media B2B use in industrial marketing context: customers' view”, Journal of Business \& Industrial Marketing, Vol. 30 No. 6, pp. 711-722.

Kock, S., Nisuls, J. and Soderqvist, A. (2010), "Coopetition: a source of international opportunities in Finnish SMEs", Competitiveness Review: An International Business Journal, Vol. 20 No. 2, pp. 111125.

Kor, Y.Y. and Mesko, A. (2013), "Dynamic managerial capabilities: configuration and orchestration of top executives' capabilities and the firm's dominant logic", Strategic Management Journal, Vol. 32 No. 2, pp. 233-244.

Kot, M.T. and Leszczynski, G. (2020), "The concept of intelligent agent in business interactions: is virtual assistant an actor or a boundary object?", Journal of Business \& Industrial Marketing (forthcoming).

Kozlenkova, I., Samaha, S. and Palamatier, R.W. (2014), "Resource-based theory in marketing", Journal of the Academy of Marketing Science, Vol. 42 No. 1, pp. 1-21.

Kumar, V. and Pansari, A. (2016), "Competitive advantage through engagement", Journal of Marketing Research, Vol. 53 No. 4, pp. 497-514.

Lai, C-S., Chan, D.Y-C., Yang, C-F. and Hsu, W-C. (2015), "The value creation scale of supplierdistributor relationship in international markets", Journal of Business \& Industrial Marketing, Vol. 30 No. 2, pp. 171-181.

Lapierre, J. (2000), "Customer-perceived value in industrial contexts", Journal of Business \& Industrial Marketing, Vol. 15 Nos. 2/3, pp. 122-145.

Lascaux, A. (2020), "Coopetition and trust: what we know, where to go next", Industrial Marketing, Management, Vol. 84 No. 1, pp. 2-18.

Lavie, D. (2006), "The competitive advantage of inter-connected firms: an extension of the resourcebased view", Academy of Management Review, Vol. 31 No. 3, pp. 638-658.

Leckie, C., Widing, R. and Whitwell, G. (2017), "Manifest conflict, customer orientation and performance outcomes in international buyer-seller relationships", Journal of Business \& Industrial Marketing, Vol. 32 №. 8, pp. 1062-1072. 
Leite, E., Pahlberg, C. and Aberg, S. (2018), "The cooperation-competition interplay in the ICT industry", Journal of Business \& Industrial Marketing, Vol. 33 No. 4, pp. 495-505.

Leonidou, L.C. (1995), "Export barriers: non-exporters' perceptions”, International Marketing Review, Vol. 12 No. 1 , pp. 4-25.

Lindell, M.K. and Whitney, D.J. (2001), "Accounting for common method variance in cross-sectional research designs", Journal of Applied Psychology, Vol. 86 No. 1, pp. 114-121.

Lin, M-J.J. and Huang, C-H. (2013), "The impact of customer participation on NPD performance: the mediating role of inter-organisation relationship", Journal of Business \& Industrial Marketing, Vol. 28 No. 1, pp. 3-15.

Liu, Y., Deng, P., Wei, J., Ying, Y. and Tian, M. (2019), "International R\&D alliances and innovation for emerging market multinationals: roles of environmental turbulence and knowledge transfer", Journal of Business \& Industrial Marketing, Vol. 34 No. 6, pp. 1374-1387.

Luo, X., Rindfleisch, A. and Tse, D.K. (2007), "Working with rivals: the impact of competitor alliances on financial performance", Journal of Marketing Research, Vol. 44 No. 1, pp. 73-83.

Luo, Y. (2005), "Toward coopetition within a multinational enterprise: a perspective from foreign subsidiaries", Journal of World Business, Vol. 40 No. 1, pp. 71-90.

Luo, Y. and Tung, R.L. (2007), "International expansion of emerging market enterprises: a springboard perspective”, Journal of International Business Studies, Vol. 38 No. 1, pp. 481-498.

Mattsson, L-G. and Tidstrom, A. (2015), "Applying the principles of Yin-Yang to market dynamics: on the duality of cooperation and competition", Marketing Theory, Vol. 15 No. 3, pp. 347-364.

McGrath, H., O'Toole, T. and Canning, L. (2019), "Coopetition: a fundamental feature of entrepreneurial firms' collaborative dynamics", Journal of Business \& Industrial Marketing, Vol. 34 No. 7, pp. 15551569.

Miles, M.B. and Huberman, A.M. (1994), Qualitative Data Analysis: An Expanded Sourcebook, second edition, Sage Publications Limited, Thousand Oaks: CA.

Moller, K. (2013), "Theory map of business marketing: relationships and networks perspectives", Industrial Marketing Management, Vol. 43 No. 3, pp. 324-335.

Morgan, N.A. (2012), "Marketing and business performance", Journal of the Academy of Marketing Science, Vol. 40 No. 1, pp. 102-119.

Morgan, N.A., Vorhies, D.W. and Mason, C.H. (2009), "Market orientation, marketing capabilities, and firm performance", Strategic Management Journal, Vol. 30 No. 8, pp. 909-920.

Morgan, R.M. and Hunt, S.D. (1994), "The commitment-trust theory of relationship marketing", Journal of Marketing, Vol. 58 No. 3, pp. 20-38.

Mu, J., Bao, Y., Sekhon, T., Qi, J. and Lowe, E. (2018), "Outside-in marketing capability and firm performance", Industrial Marketing Management, Vol. 75 No. 1, pp. 37-54.

Narver, J.C. and Slater, S.F. (1990), "The effect of a market orientation on business profitability", Journal of Marketing, Vol. 54 No. 4, pp. 20-35.

Nordin, F. and Lindbergh, J. (2019), "Foreign market learning: an integrative model of its antecedents, processes and outcomes", Journal of Business \& Industrial Marketing, Vol. 34 No. 6, pp. 1248-1258. 
O'Cass, A., Ngo, L.V. and Siahtiri, V. (2015), "Marketing resource-capability complementarity and firm performance in B2B firms", Journal of Business \& Industrial Marketing, Vol. 30 No. 2, pp. 194-207.

O'Dwyer, M., Gilmore, A. and Carson, D. (2011), "Strategic alliances as an element of innovative marketing in SMEs", Journal of Strategic Marketing, Vol. 19 No. 1, pp. 91-104.

Olson, E.M., Slater, S.F. and Hult, G.T.M. (2005), "The performance implications of fit among business strategy, marketing organization structure, and strategic behavior", Journal of Marketing, Vol. 69 No. 3, pp. 49-65.

Ozturan, P., Ozsomer, A. and Pieters, R. (2014), "The role of market orientation in advertising spending during economic collapse: the case of Turkey in 2001", Journal of Marketing Research, Vol. 51 No. 2, pp. 139-152.

Park, B.J.R., Srivastava, M.K. and Gnyawali, D.R. (2014), "Walking the tightrope of coopetition: impact of competition and cooperation intensities and balance on firm innovation performance", Industrial Marketing Management, Vol. 43 No. 2, pp. 210-221.

Pehrsson, A. (2014), "Firms' customer responsiveness and performance: the moderating roles of dyadic competition and firm's age", Journal of Business \& Industrial Marketing, Vol. 29 No. 1, pp. 34-44.

Peng, M.W. and Luo, Y. (2000), "Managerial ties and firm performance in a transition economy: the nature of a micro-macro link", Academy of Management Journal, Vol. 43 No. 3, pp. 486-501.

Peteraf, M.A. (1993), "The cornerstones of competitive advantage: a resource-based view", Strategic Management Journal, Vol. 14 No. 3, pp. 179-191.

Peter, J.P. (1981), "Construct validity: a review of basic issues and marketing practices", Journal of Marketing Research, Vol. 18 No. 2, pp. 133-145.

Peterson, R.A. (2000), "A meta-analysis of variance accounted for and factor loadings in exploratory factor analysis", Marketing Letters, Vol. 11 No. 3, pp. 261-275.

Ping Jr., R.A. (1995), "A parsimonious estimating technique for interaction and quadratic latent variables", Journal of Marketing Research, Vol. 32 No. 3, pp. 336-347.

Podsakoff, P.M., Mackenzie, S.B., Lee, J.Y. and Podsakoff, N.P. (2003), "Common method biases in behavioral research: a critical review of the literature and recommended remedies", Journal of Applied Psychology, Vol. 88 No. 5, pp. 879-903.

Prahalad, C.K. and Bettis, R.A. (1986), "The dominant logic: a new linkage between diversity and performance", Strategic Management Journal, Vol. 7 No. 6, pp. 485-501.

Priem, R.L. and Butler, J.E. (2001), "Is the resource-based view a useful perspective for strategic management research?", Academy of Management Review, Vol. 26 No. 1, pp. 22-40.

Ray, G., Barney, J.B. and Muhanna, W.A. (2004), "Capabilities, business processes, and competitive advantage: choosing the dependent variable in empirical tests of the resource-based view", Strategic Management Journal, Vol. 25 No. 1, pp. 23-37.

Raza-Ullah, T., Bengtsson, M. and Kock, S. (2014), "The coopetition paradox and tension in coopetition at multiple-levels", Industrial Marketing Management, Vol. 43 No. 2, pp. 189-198.

Reynolds, N. and Diamantopoulos, A. (1998), "The effect of pre-test method on error detection rates: experimental evidence", European Journal of Marketing, Vol. 32 Nos. 5/6, pp. 480-498. 
Rich, M.K. (2003), "Requirements for successful marketing alliances", Journal of Business \& Industrial Marketing, Vol. 18 Nos. 4/5, pp. 447-456.

Rindfleisch, A. and Moorman, C. (2003), "Inter-firm cooperation and customer orientation", Journal of Marketing Research, Vol. 40 No. 4, pp. 421-436.

Ritala, P. (2012), "Coopetition strategy - when is it successful? Empirical evidence on innovation and market performance", British Journal of Management, Vol. 23 No. 3, pp. 307-324.

Ritala, P., and Hurmelinna-Laukkanen, P. (2013), "Incremental and radical innovation in coopetition: the role of absorptive capacity and appropriability", Journal of Product Innovation Management, Vol. 30 No. 1, pp. 154-169.

Robson, M.J., Schlegelmilch, B.B. and Bojkowszky, B. (2012), "Resource deployment stability and performance in international research-and-development alliances: a self-determination theory explanation", Journal of International Marketing, Vol. 20 No. 1, pp. 1-18.

Rusko, R. (2011), "Exploring the concept of coopetition: a typology for the strategic moves of the Finnish forest industry", Industrial Marketing Management, Vol. 40 No. 2, pp. 311-320.

Russo, I., Confente, I., Gligor, D.M. and Cobelli, N. (2017), "The impact of service encounter quality in service evaluation: evidence from a business-to-business context", Journal of Business \& Industrial Marketing, Vol. 32 No. 5, pp. 664-676.

Ryan, P., Evers, N., Smith, A. and Andersson, S. (2019), "Local horizontal network membership for accelerated global market reach", International Marketing Review, Vol. 36 No. 1, pp. 6-30.

Safari, A. and Saleh, A.S. (2020), "Key determinants of SMEs' export performance: a resource-based view and contingency theory approach using potential mediators", Journal of Business \& Industrial Marketing, Vol. 35 No. 4, pp. 635-654.

Shu, C., Jin, J.L. and Zhou, K.Z. (2017), "A contingent view of partner coopetition in international joint ventures", Journal of International Marketing, Vol. 25 No. 3, pp. 42-60.

Slater, S.F. and Narver, J.C. (2000), "Intelligence generation and superior customer value", Journal of the Academy of Marketing Science, Vol. 28 No. 1, pp. 120-127.

Smith, T.M., Hama, K. and Smith, P.M. (2003), "The effect of successful trade show attendance on future show interest: exploring Japanese attendee perspectives of domestic and offshore international events", Journal of Business \& Industrial Marketing, Vol. 18 Nos. 4/5, pp. 403-418.

Spiller, S.A., Fitzsimons, G.J., Lynch, J.G. and McClelland, G.H. (2013), "Spotlights, floodlights, and the magic number zero: simple effects tests in moderated regression", Journal of Marketing Research, Vol. 50 No. 2, pp. 277-288.

Sraha, G., Sharma, R.R., Crick, D. and Crick, J.M. (2020), "International experience, export commitment, distribution adaptation, and performance: a study of Ghanaian firms in B2B export markets", Journal of Business \& Industrial Marketing (forthcoming).

Steenkamp, J-B.E.M. and Baumgartner, H. (2000), "On the use of structural equation models for marketing modelling", International Journal of Research in Marketing, Vol. 17 Nos. 2/3, pp. 195-202.

Suddaby, R. (2006), "From the editors: what grounded theory is not", Academy of Management Journal, Vol. 49 No. 4, pp. 633-642.

Telfer, D.J. (2001), "Strategic alliances along the Niagara wine route", Tourism Management, Vol. 22 No. 1, pp. 21-30. 
Tidstrom, A. (2009), "Causes of conflict in inter-competitor cooperation", Journal of Business \& Industrial Marketing, Vol. 24 No. 7, pp. 506-518.

Tidstrom, A. (2014), "Managing tensions in coopetition", Industrial Marketing Management, Vol. 43 No. 2, pp. 261-271.

Tidstrom, A., Ritala, P. and Lainema, K. (2018), "Interactional and procedural practices in managing coopetitive tensions", Journal of Business \& Industrial Marketing, Vol. 33 No. 7, pp. 945-957.

Tikkanen, H. (1998), "The network approach in analyzing international marketing and purchasing operations: a case study of a European SME's focal net 1992-95", Journal of Business \& Industrial Marketing, Vol. 13 No. 2, pp. 109-131.

Vorhies, D.W. and Morgan, N.A. (2005), "Benchmarking marketing capabilities for sustainable competitive advantage", Journal of Marketing, Vol. 69 No. 1, pp. 80-94.

Vorhies, D.W., Orr, L.M. and Bush, V.D. (2011), "Improving customer-focused marketing capabilities and firm financial performance via marketing exploration and exploitation", Journal of the Academy of Marketing Science, Vol. 39 No. 5, pp. 736-756.

Wernerfelt, B. (1984), "A resource-based view of the firm", Strategic Management Journal, Vol. 5 No. 2 , pp. 171-180.

Wernerfelt, B. (2014), "On the role of the RBV in marketing", Journal of the Academy of Marketing Science, Vol. 42 No. 1, pp. 22-23.

Wheeler, C., Jones, M.V. and Young, S. (1996), "Market entry modes and channels of distribution in the UK machine tool industry", European Journal of Marketing, Vol. 30 No. 4, pp. 40-57.

Xie, Y. and Zheng, Z. (2019), "How does corporate learning orientation enhance industrial brand equity? The roles of firm capabilities and size", Journal of Business \& Industrial Marketing, Vol. 35 No. 2, pp. 231-243.

Yan, Y., Dong, J.Q. and Faems, D. (2020), "Not every coopetitor is the same: the impact of technological, market and geographical overlap with coopetitors on firms' breakthrough inventions", Long Range Planning (forthcoming). 
Figure 1. Conceptual framework

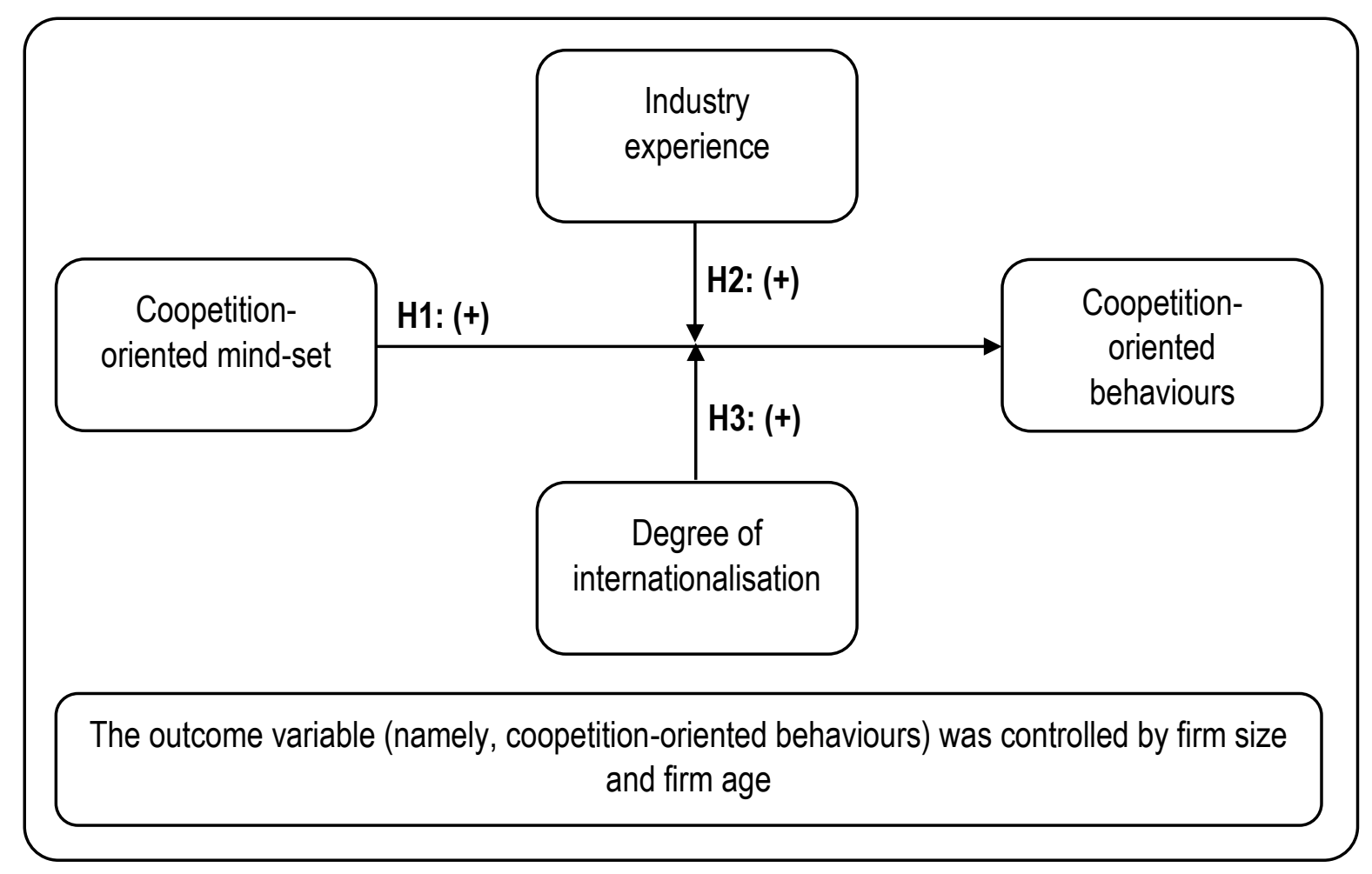


Figure 2. Moderating effects of industry experience

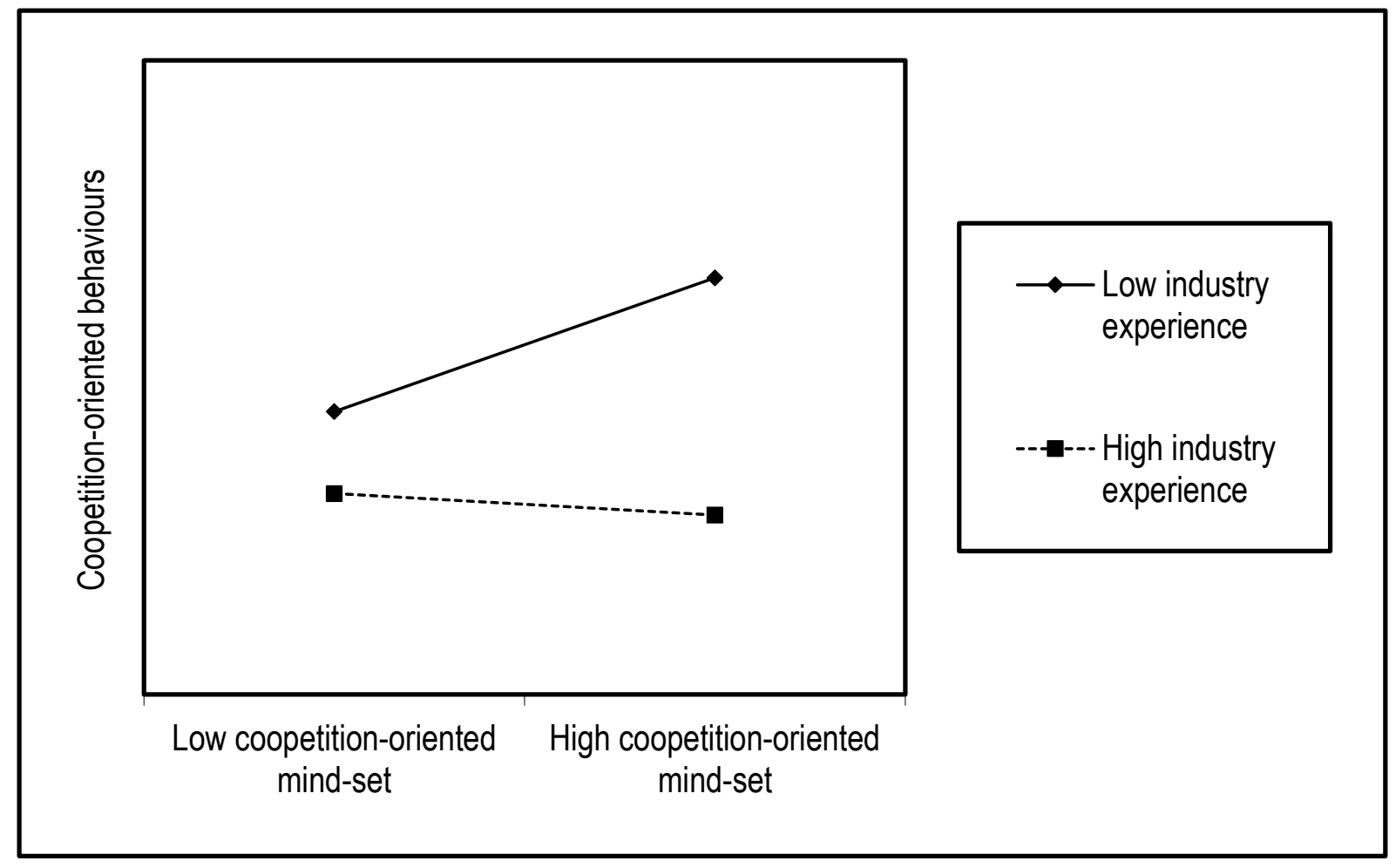

Figure 3. Moderating effects of degree of internationalisation

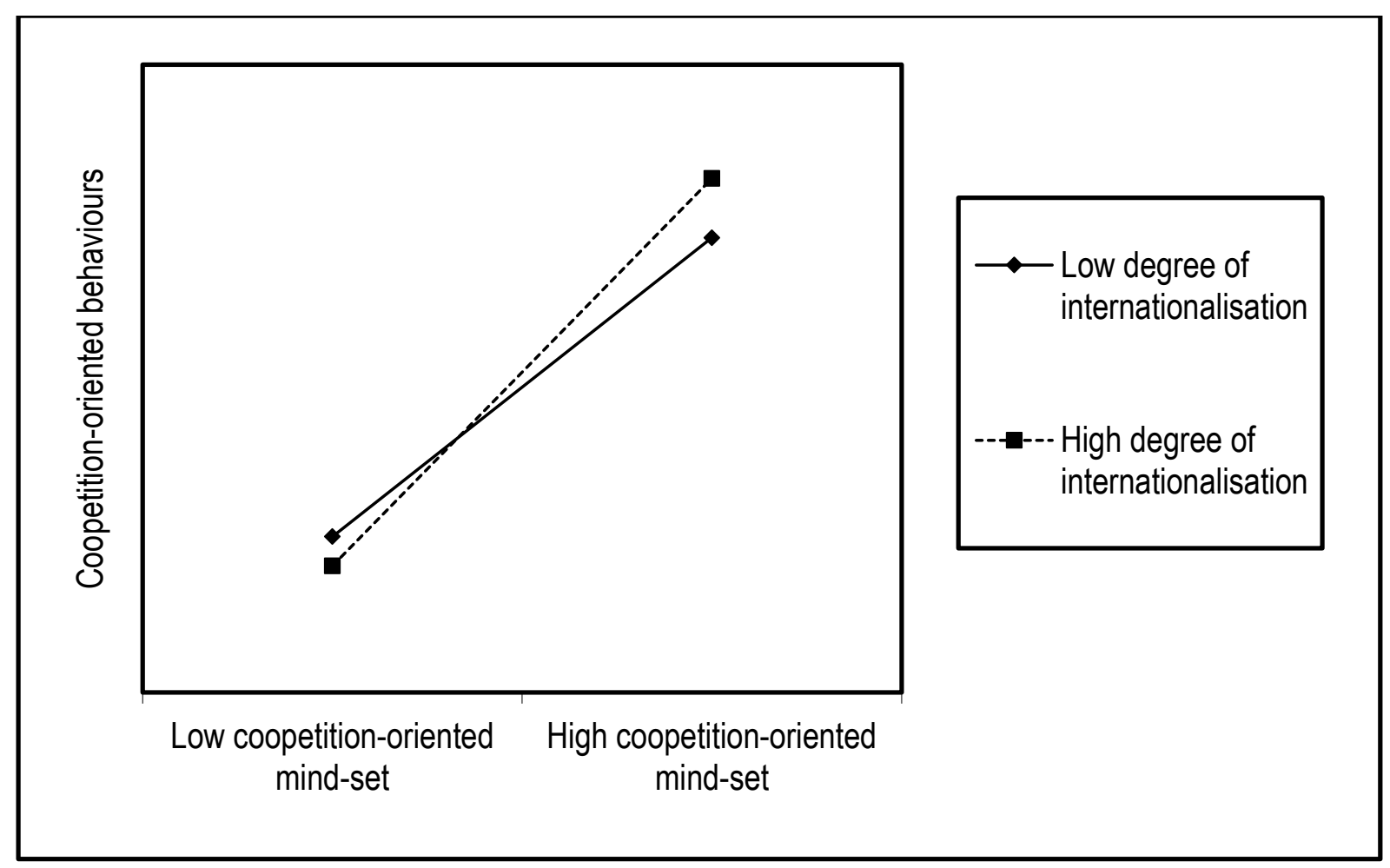


Table 1. Characteristics of the final sample

\begin{tabular}{|l|c|c|c|c|}
\hline Characteristics & Mean & SD & Min & Max \\
\hline Number of seasonal employees & 48.55 & 60.32 & 0.00 & 200.00 \\
\hline Number of part-time employees & 38.67 & 58.34 & 0.00 & 200.00 \\
\hline Number of full-time employees & 32.92 & 54.24 & 0.00 & 200.00 \\
\hline Firm age (years) & 150.47 & 39.61 & 1.00 & 185.00 \\
\hline Industry experience (years) & 20.66 & 15.03 & 0.39 & 60.00 \\
\hline Years in current role & 14.33 & 13.90 & 0.34 & 60.00 \\
\hline Years in current organisation & 16.80 & 14.75 & 0.59 & 60.00 \\
\hline Export ratio (\%) & 25.26 & 31.37 & 0.00 & 100.00 \\
\hline Number of export markets & 11.89 & 21.09 & 0.00 & 147.00 \\
\hline Note: The w
\end{tabular}

Note: These wine producers engaged in outwards forms of internationalisation, such as exporting either on an ad-hoc basis or through agents and/or distributors. Further, they were involved with inwards internationalisation activities, including hiring foreign-born members of staff, sourcing equipment from abroad, and serving customers visiting from other countries (e.g., through wine tourism services). In short, the final sample was comprised of internationalised organisations. 
Table 2. Exploratory factor analysis model

\begin{tabular}{|l|c|c|c|c|}
\hline & \multicolumn{4}{|c|}{ Components } \\
\hline Items & Factor 1 & Factor 2 & Factor 3 & Factor 4 \\
\hline CM_1 & $\mathbf{0 . 8 1}$ & 0.24 & 0.34 & 0.31 \\
\hline CM_4 & $\mathbf{0 . 8 1}$ & 0.29 & 0.31 & 0.30 \\
\hline CM_6 & $\mathbf{0 . 8 1}$ & 0.30 & 0.30 & 0.30 \\
\hline LLC_1 & 0.18 & $\mathbf{0 . 7 6}$ & 0.36 & 0.16 \\
\hline LLC_2 & 0.31 & $\mathbf{0 . 7 6}$ & 0.23 & 0.24 \\
\hline LLC_5 & 0.26 & $\mathbf{0 . 7 5}$ & 0.19 & 0.29 \\
\hline NLC_1 & 0.37 & 0.36 & $\mathbf{0 . 8 4}$ & 0.35 \\
\hline NLC_4 & 0.39 & 0.34 & $\mathbf{0 . 8 5}$ & 0.35 \\
\hline NLC_6 & 0.38 & 0.34 & $\mathbf{0 . 8 3}$ & 0.34 \\
\hline OLC_1 & 0.42 & 0.35 & 0.37 & $\mathbf{0 . 7 1}$ \\
\hline OLC_2 & 0.45 & 0.31 & 0.41 & $\mathbf{0 . 7 0}$ \\
\hline OLC_6 & 0.39 & 0.35 & 0.39 & $\mathbf{0 . 7 0}$ \\
\hline NC_ & & & &
\end{tabular}

Note: The indicators presented in a bold font were used to measure each latent variable within the four-factor solution.

Table 3. Confirmatory factor analysis model

\begin{tabular}{|l|c|c|c|c|}
\hline & \multicolumn{2}{|c|}{ Factor loadings $(\boldsymbol{\lambda} \mathbf{x})$} & \multicolumn{2}{c|}{ Error variances $(\boldsymbol{\theta} \boldsymbol{\delta})$} \\
\hline Items & $\boldsymbol{\lambda} \mathbf{x}$ & $\boldsymbol{t}$-values & $\boldsymbol{\theta} \boldsymbol{\delta}$ & $\boldsymbol{t}$-values \\
\hline CM_1 & 0.95 & Fixed & 0.10 & 6.45 \\
\hline CM_4 & 0.94 & 26.71 & 0.12 & 6.91 \\
\hline CM_6 & 0.94 & 26.37 & 0.12 & 7.07 \\
\hline LLC_1 & 0.99 & Fixed & 0.02 & 3.28 \\
\hline LLC_2 & 0.98 & 55.12 & 0.04 & 5.95 \\
\hline LLC_5 & 0.94 & 36.08 & 0.11 & 8.91 \\
\hline NLC_1 & 0.93 & Fixed & 0.14 & 6.53 \\
\hline NLC_4 & 0.91 & 21.89 & 0.16 & 7.11 \\
\hline NLC_6 & 0.90 & 20.79 & 0.20 & 7.67 \\
\hline OLC_1 & 0.96 & 36.19 & 0.08 & 6.93 \\
\hline OLC_2 & 0.98 & Fixed & 0.04 & 4.45 \\
\hline OLC_6 & 0.92 & 28.89 & 0.15 & 8.49 \\
\hline SIZE & 1.00 & Fixed & 0.00 & Fixed \\
\hline AGE & 1.00 & Fixed & 0.00 & Fixed \\
\hline INDS & 1.00 & Fixed & 0.00 & Fixed \\
\hline INTL & 1.00 & Fixed & 0.00 & Fixed \\
\hline MARKER & 1.00 & Fixed & 0.00 & Fixed \\
\hline Note: The critical $t$-value was 1.65 (5\%, one-sided). \\
\hline
\end{tabular}


Table 4. Final scale reliabilities and the discriminant validity test

\begin{tabular}{|c|c|c|c|c|c|c|c|c|c|}
\hline Latent variables & 1. & 2. & 3. & 4. & 5. & 6. & 7. & 8. & 9. \\
\hline 1. Coopetition-oriented mind-set & 1.00 & & & & & & & & \\
\hline 2. Local-level coopetition & 0.66 & 1.00 & & & & & & & \\
\hline 3. National-level coopetition & 0.46 & 0.55 & 1.00 & & & & & & \\
\hline 4. Organisation-level coopetition & 0.74 & 0.76 & 0.53 & 1.00 & & & & & \\
\hline 5. Industry experience & 0.10 & 0.23 & 0.50 & 0.17 & 1.00 & & & & \\
\hline 6. Firm size & 0.07 & 0.12 & 0.26 & 0.10 & 0.28 & 1.00 & & & \\
\hline 7. Firm age & 0.06 & 0.12 & 0.41 & 0.11 & 0.53 & 0.19 & 1.00 & & \\
\hline 8. Degree of internationalisation & 0.27 & 0.36 & 0.42 & 0.34 & 0.28 & 0.14 & 0.30 & 1.00 & \\
\hline 9. Informant quality (marker variable) & 0.00 & 0.00 & 0.01 & 0.00 & 0.04 & 0.01 & 0.04 & 0.00 & 1.00 \\
\hline Alpha $(\alpha)$ & 0.96 & 0.98 & 0.94 & 0.97 & - & - & - & - & - \\
\hline CR & 0.96 & 0.98 & 0.94 & 0.97 & - & - & - & - & - \\
\hline AVE & 0.89 & 0.94 & 0.83 & 0.91 & - & - & - & - & - \\
\hline
\end{tabular}


Table 5. Bivariate correlations and descriptive statistics

\begin{tabular}{|c|c|c|c|c|c|c|c|c|c|}
\hline Latent variables & 1. & 2. & 3. & 4. & 5. & 6. & 7. & 8. & 9. \\
\hline 1. Coopetition-oriented mind-set & 1.00 & & & & & & & & \\
\hline 2. Local-level coopetition & 0.79 & 1.00 & & & & & & & \\
\hline 3. National-level coopetition & 0.64 & 0.72 & 1.00 & & & & & & \\
\hline 4. Organisation-level coopetition & 0.83 & 0.86 & 0.71 & 1.00 & & & & & \\
\hline 5. Coopetition-oriented behaviours & 0.82 & 0.93 & 0.89 & 0.93 & 1.00 & & & & \\
\hline 6. Industry experience & 0.51 & 0.59 & 0.63 & 0.58 & 0.66 & 1.00 & & & \\
\hline 7. Degree of internationalisation & 0.24 & 0.34 & 0.63 & 0.33 & 0.48 & 0.55 & 1.00 & & \\
\hline 8. Firm size & 0.32 & 0.47 & 0.69 & 0.42 & 0.58 & 0.53 & 0.73 & 1.00 & \\
\hline 9. Firm age & -0.26 & -0.35 & -0.50 & -0.32 & -0.43 & -0.37 & -0.44 & -0.53 & 1.00 \\
\hline Mean & 5.15 & 4.63 & 4.07 & 4.76 & 4.55 & 2.71 & 2.10 & 3.79 & 4.93 \\
\hline SD & 1.62 & 1.54 & 1.65 & 1.54 & 1.44 & 0.89 & 1.74 & 1.48 & 0.57 \\
\hline Min & 1.00 & 1.00 & 1.00 & 1.00 & 1.00 & 0.10 & 0.00 & 0.69 & 0.00 \\
\hline Max & 7.00 & 7.00 & 7.00 & 7.00 & 7.00 & 4.09 & 4.61 & 6.40 & 5.22 \\
\hline
\end{tabular}

Note: All correlations were significant at the $1 \%$ level (two-tailed tests). Coopetition-oriented behaviours was a composite variable - an average of local-level coopetition, national-level coopetition, and organisation-level coopetition. 
Table 6. Hierarchical regression analysis

\begin{tabular}{|c|c|c|c|c|c|c|c|c|c|c|c|c|}
\hline & \multicolumn{2}{|c|}{ Step 1} & \multicolumn{2}{|c|}{ Step 2} & \multicolumn{2}{|c|}{ Step 3} & \multicolumn{2}{|c|}{ Step 4} & \multicolumn{2}{|c|}{ Step 5} & \multicolumn{2}{|c|}{ Step 6} \\
\hline Paths & $\beta$ & $t$-values & $\beta$ & $t$-values & $\beta$ & $t$-values & $\beta$ & $t$-values & $\beta$ & $t$-values & $\beta$ & $t$-values \\
\hline SIZE & 0.48 & $7.13^{* * *}$ & 0.31 & $7.92^{* \star *}$ & 0.25 & $6.12^{* \star *}$ & 0.22 & $4.44^{* * *}$ & 0.22 & $4.49^{* * *}$ & 0.21 & $4.27^{\star \star *}$ \\
\hline AGE & -0.42 & $-2.45^{\star *}$ & -0.19 & $-1.88^{*}$ & -0.15 & -1.61 & -0.15 & -1.54 & -0.17 & $-1.70^{*}$ & -0.12 & -1.17 \\
\hline $\mathrm{CM}$ & & & 0.63 & $19.97^{* \star \star}$ & 0.57 & $17.12^{* \star \star}$ & 0.57 & $17.10^{* \star \star}$ & 0.54 & $10.87^{* * *}$ & 0.57 & $11.16^{* * \star}$ \\
\hline INDS & & & & & 0.28 & $4.16^{* * *}$ & 0.26 & $3.65^{* * *}$ & 0.35 & $2.60^{* *}$ & 0.52 & $3.35^{* * *}$ \\
\hline INTL & & & & & & & 0.04 & 1.01 & 0.04 & 1.02 & -0.23 & $-1.72^{*}$ \\
\hline CMxINDS & & & & & & & & & -0.02 & -0.02 & -0.06 & $-1.82^{*}$ \\
\hline CMxINTL & & & & & & & & & & & 0.05 & $2.14^{* *}$ \\
\hline & & & & & & & & & & & & \\
\hline Model fit & & & & & & & & & & & & \\
\hline $\mathrm{R}^{2}$ & 0.35 & & 0.79 & & 0.80 & & 0.80 & & 0.80 & & 0.81 & \\
\hline Adjusted $\mathrm{R}^{2}$ & 0.35 & & 0.79 & & 0.80 & & 0.80 & & 0.80 & & 0.81 & \\
\hline Changes & & & & & & & & & & & & \\
\hline$\Delta \mathrm{R}^{2}$ & 0.35 & & 0.44 & & 0.01 & & 0.00 & & 0.00 & & 0.01 & \\
\hline$\Delta F$ & $52.48^{\star \star *}$ & . & $398.83^{* * *}$ & & $17.30^{\star \star \star}$ & & 1.03 & & 0.61 & & $4.58^{* *}$ & \\
\hline
\end{tabular}




\section{Appendix 1. Full-list of the multi-item measurement scales}

\section{Coopetition-oriented mind-set}

In our organization...

- CM_1 - ... we believe in the importance of cooperating with competing firms

- CM_2 - ... we perceive that it is effective to collaborate with competitors

- CM_3 - ... we feel that it is vital to collaborate with our rivals

- CM_4 - ... we have a mind-set focused on cooperating with competitors

- CM_5 - ... we believe that firms should share assets (equipment, etc.) with their rivals

- CM_6 - ... cooperating with competitors is likely to improve our performance

Anchors: 1 = very strongly disagree to 7 = very strongly agree (adapted from Crick and Crick, 2019).

\section{Local-level coopetition}

In our organization...

- LLC_1 - ... we regularly share assets (equipment, etc.) with our local competitors

- LLC_2 - ... we frequently help local rivals by sharing assets (equipment, etc.)

- LLC_3 - ... we often cooperate with our competitors at a local-level

- LLC_4 - ... we usually collaborate with geographically-close competitors

- LLC_5 - ... we borrow equipment (equipment, etc.) from rivals in our local area

- LLC_6 - ... we have positive networks with competitors in this region

Anchors: 1 = very strongly disagree to 7 = very strongly agree (adapted from Crick and Crick, 2019).

\section{National-level coopetition}

In our organization...

- NLC_1 - ... we share assets (equipment, etc.) with our rivals throughout the nation

- NLC_2 - ... we have positive networks with our competitors across the country

- NLC_3 - ... we are highly-cooperative with our competitors in other regions

- NLC_4 - ... we share assets (equipment, etc.) with competitors outside of our region

- NLC_5 - ... we collaborate with our rivals in multiple regions

- NLC_6 - ... we collaborate with our rivals all over the country

Anchors: 1 = very strongly disagree to 7 = very strongly agree (adapted from Crick and Crick, 2019).

\section{Organisation-level coopetition}

In our organization...

- OLC_1 - ... we regularly cooperate with non-wine competitors

- OLC_2 - ... we have positive ties with non-wine rival businesses

- OLC_3 - ... we pool assets (equipment, etc.) with rivals outside of the wine sector

- OLC_4 - ... we frequently collaborate with non-wine competing companies

- OLC_5 - ... we borrow and lend assets (equipment, etc.) with non-wine rival firms

- OLC_6 - ... we have positive networks with non-wine competitors 
Anchors: 1 = very strongly disagree to $7=$ very strongly agree (adapted from Crick and Crick, 2019). The measurement items for organisation-level coopetition featured a reference to indirect rivals being entities, such as breweries (to serve as an example).

\section{Informant quality}

In closing to the survey:

- INQ_1 - I am confident about my answers to the questions above

- INQ_2 - This survey deals with issues that I am knowledgeable about

- INQ_3 - I am a qualified person to complete this survey

- INQ_4 - My current role allows me to have answered the questions above

Anchors: 1 = very strongly disagree to 7 = very strongly agree (adapted from Hultman et al., 2009). 